\title{
TAKING A SECOND LOOK AT MDL PRODUCT LIABILITY SETTLEMENTS: SOMEBODY NEEDS TO DO IT
}

\author{
Christopher B. Mueller*
}

\section{INTRODUCTION}

Several generations ago a great economist began a book with the wry observation that science says the bumblebee can't fly (it is "a successful but an insecure insect"). ${ }^{1}$ American capitalism, John Kenneth Galbraith went on to say, resembles the bumblebee-it can't fly either, but somehow it does. ${ }^{2}$ The same may be said of multidistrict litigation (MDL) when it leads to aggregate settlement of product liability claims, especially those involving allegedly faulty drugs, which (along with claims arising from sales and service practices) make up more than a third of the thousands of federal cases gathered "for pretrial purposes" in various federal "transferee" courts. ${ }^{3}$

The practice of MDL settlements of product liability cases has been subjected to devastating criticism on multiple grounds, and yet it keeps on flying. MDL in these settings can actually be called "illegal." As critics have persuasively argued, this use of MDL is not authorized by law, does not fit within the purposes of the statute on which it rests, it is purposefully employed to avoid the safeguards that federal courts, including the Supreme Court, erected to protect the rights of claimants. Equally concerning, MDL settlements of product liability cases are unfair to many claimants and the lawyers that represent them, lead the lawyers driving these things into questionable (if not unethical) behavior,

\footnotetext{
* Henry S. Lindsley Professor of Law, University of Colorado Law School. I wish especially to thank Fred Bloom, Rick Collins, Rick Marcus, Pierre Schlag, and Patrick Woolley for providing extended written comments on an earlier draft, and to thank them and other colleagues of mine at Colorado who attended a work-in-progress and made many helpful comments.

1. John Kenneth Galbraith, American Capitalism: The Concept of COUNTERVAILING Power 1 (1956) (likening "the American economy" to the Bumblebee).

2. See id.

3. See U.S. Judicial Panel on Multidist. Litig., Distribution of Pending MDLs by Type, in U.S. Judicial Panel on Multidistrict Litigation: Calendar Year Statistics (2015), http://www.jpml.uscourts.gov/sites/jpml/files/JPML_Calendar_Year_Statistics-2015.pdf.
} 
lead courts to perform functions they are ill suited for, may well violate standards of due process, and have only the most tenuous claim to democratic legitimacy.

So why do MDL mass tort settlements survive? Examining this question seems worthwhile because this bumblebee is going to keep on flying. Unlike the actual bumblebee, however, which confers benefits social and ecological and brings little risk to humanity, MDL mass tort settlements pose huge risks that are going unchecked. We now know why the real bumblebee can fly: Its wings are too small, but it can fly because they "clap together" just before the bumblebee lifts off, creating enough vacuum to get it aloft. The wings are so flexible that they can do what science had thought impossible. Apparently the wings of MDL mass tort settlements can "clap together" too, and it is worthwhile to see how they accomplish this feat.

This article argues that we need a checking mechanism for the MDL mass tort settlement - a form of review that would bring to bear a real adversary process in a court that has not already invested its energies and prestige in the settlement itself. In short, it should be possible to mount a collateral challenge to the MDL mass tort settlement, brought by any claimant in the gathered suits that resulted in the settlement. A second court should be able to address the adequacy of the settlement and to resolve the question whether the original lawyers adequately represented sidelined claimants whose interests were entrusted to a plaintiffs' management committee by the judge in the transferee forum. Class action settlements require fairness examinations by the rendering court, and there is strong disagreement in the literature on the question (and appropriate scope) of collateral challenge to such settlements. There is currently no mechanism for collateral challenge to MDL settlements, which is - at one and the same time - one of the reasons why they have become popular and one of the reasons why they are so much at odds with our basic ideas about procedure and fairness.

\section{The Rise Of MDL AgGREgative SETtLEMENTS}

Enacted in 1968 to deal with a flood of lawsuits alleging conspiracy in the electrical equipment industry (some 1,800 suits had been filed across the country), the Multi-District Litigation Statute created a panel of federal judges empowered to transfer pending federal cases to a single judge for purposes of pretrial discovery. ${ }^{4}$ The statute has a low threshold

4. See Edward F. Sherman, The MDL Model for Resolving Complex Litigation if a Class 
of commonality, allowing transfer of cases involving "one or more common questions of fact." It authorizes transfer of cases solely for pretrial purposes, providing that each transferred action "shall be remanded" to the court of original filing "at or before" the conclusion of pretrial proceedings. ${ }^{6}$ The Supreme Court held years ago that the gathered cases cannot go forward to trial in the transferee forum, ${ }^{7}$ and indeed the electrical equipment cases were not tried or settled in the transferee forum either, but continued to be resolved in the courts in which they were initially filed. ${ }^{8}$ Nevertheless, it is a remarkable fact that almost none of the cases gathered in a single forum under the MDL procedures ever returns to the original court: Almost all settle in the transferee forum or are finally resolved in other ways. ${ }^{9}$

While it was once the case that only a few judges presided in transferee fora in MDL cases, and they were a tiny fraction of the civil docket, now they make up a significant part of the federal civil docket and occupy the time of many trial judges. ${ }^{10}$ Literally thousands of suits have been gathered under MDL procedures, including many mass tort cases, particularly in the areas of drug litigation where the Vioxx and Zyprexa cases are modern paradigms. In the Vioxx cases, the claim was that a painkiller increased substantially the risk of heart attack and stroke. ${ }^{11}$ In the Zyprexa cases, the claim was that a drug approved for the

Action Is Not Possible, 82 TUL. L. Rev. 2205, 2205-06 (2008); Mark Herrmann \& Pearson Bownas, An Uncommon Focus on "Common Questions": Two Problems with the Judicial Panel on Multidistrict Litigation's Treatment of the "One or More Common Questions of Fact" Requirement for Centralization, 82 Tul. L. REv. 2297, 2300-01 (2008) (citing Phil C. Neal \& Perry Goldberg, The Electrical Equipment Antitrust Cases: Novel Judicial Administration, 50 A.B.A. J. 621, 622 (1964)).

5. 28 U.S.C. $\S 1407$ (a) (2012).

6. Id.

7. Lexecon, Inc. v. Milberg Weiss Bershad Hynes \& Lerach, 523 U.S. 26, $40-41$ (1998).

8. See Herrmann \& Bownas, supra note 4, at 2300-02.

9. Statistics show that the JPML has transferred 462,501 cases for pretrial, of which 13,432 were remanded $(2.9 \%), 398$ were "reassigned" for trial in transferee districts (less than .1\%), and 359,548 were "terminated in the transferee courts" (77.7\%). See Judicial Panel on Multidistrict Litigation, U.S. CTS., http://www.uscourts.gov/Statistics/JudicialBusiness/2013/judicial-panelmultidistrict-litigation.aspx [http://perma.cc/MPX2-ETC8].

10. See Jaime Dodge, Facilitative Judging: Organizational Design in Mass-Multidistrict Litigation, 64 EMORY L.J. 329, 331 (2014) [hereinafter Dodge, Facilitative Judging] (reporting that one third of federal cases are MDL matters) (citing DUKE LAW CTR. FOR JUDICIAL STUDIES, STANDARDS AND BEST PRACTICES FOR LARGE AND MASS-TORT MDLs, at $x$ (2014), https://law.duke.edu/sites/default/files/centers/judicialstudies/standards_and_best_practices_for_larg e_and_mass-tort_mdls.pdf).

11. For accounts of the Vioxx litigation, see Jeremy T. Grabill, Judicial Review of Private Mass Tort Settlements, 42 Seton Hall L. Rev. 123, 142-46 (2012); Howard M. Erichson \& Benjamin C. Zipursky, Consent Versus Closure, 96 CoRnell L. Rev. 265, 274-79 (2011) [hereinafter Erichson \& Zipursky, Consent Versus Closure]. 
treatment of schizophrenia and bipolar disorder had unwanted side effects that weren't adequately disclosed, "includ[ing] weight gain, hyperglycemia, and diabetes."12 The Volkswagen recall litigation, arising in late 2015 after news surfaced that the German car maker had rigged some half million diesel cars to fool emissions tests, ${ }^{13}$ quickly led to consolidation in the Northern District of California before Judge Breyer (brother of Justice Steven Breyer). ${ }^{14}$

It is worth noting that these mass tort settlements, accomplished by MDL procedures, are not only numerous but gigantic in terms of the aggregate amount of liability. When Judge Weinstein presided over the Agent Orange settlement of $\$ 180$ million in 1984, it was the largest settlement to date, delivering some form of recovery to 240,000 claimants (an average of $\$ 720 /$ person, although there were many who got more than that and many who got nothing). ${ }^{15}$ The 2005 Vioxx settlement of $\$ 4.85$ billion was, in inflation-adjusted terms, almost twelve times higher than Agent Orange, although the number of claimants was much smaller $(48,000)$ and average recovery is much higher (more than $\$ 100,000 /$ person). ${ }^{16}$ The settlements in the Zyprexa case (\$700 million) was also exponentially higher than Agent Orange. ${ }^{17}$ So these cases are big business, not small potatoes, and the use of MDL procedures has risen sharply in mass tort cases. ${ }^{18}$

\section{A. What Is So Attractive About This Gathering Mechanism?}

The attractions of nonclass product liability settlements are numerous: In a nutshell, judges want them and have the leverage to push parties into serious settlement talks. Lawyers for plaintiffs want them-

12. For an account of the Zyprexa litigation, see Linda S. Mullenix, Dubious Doctrines: The Quasi-Class Action, 80 U. CIN. L. REv. 389, 395-400 (2011) [hereinafter Mullenix, Dubious Doctrines].

13. Martha Neil, Dozens of VW Lawsuits Will Almost Surely Be Consolidated, but Where?,

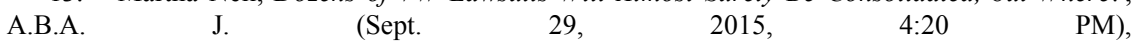
http://www.abajournal.com/news/article/dozens_of_vw_lawsuits_will_almost_surely_be_consolidat ed_but_where.

14. See In re Volkswagen "Clean Diesel” Mktg., Sales Practices, \& Prods. Liab. Litig., 148 F. Supp. 3d 1367, 1370-71 (J.P.M.L. 2015).

15. Thomas E. Willging \& Emery G. Lee III, From Class Actions to Multidistrict Consolidations: Aggregate Mass-Tort Litigation After Ortiz, 58 U. KAN. L. REV. 775, 801-02 (2010) (citing In re "Agent Orange" Prod. Liab. Litig. MDL No. 381, 818 F.2d 145, 151 (2d Cir. 1987)).

16. Id. at 802,802 tbl.2.

17. Id. at 801-02, 802 tbl.2. (citing In re Zyprexa Prods. Liab. Litig., 424 F. Supp. 2d 488, 491 (E.D.N.Y. 2006)).

18. See id. at 801 (the MDL process has "supplemented and perhaps displaced" class actions as a mechanism for large settlements). 
at least those who are given the power to run the case-for reasons of agency cost that are magnified in high-stakes litigation (whether plaintiffs themselves want them is another question, as is the question whether the sidelined lawyers for plaintiffs want them). Defendants want settlement too, being willing to sit down and bargain for the nearest thing they can get to a global resolution that enables them to "move beyond" carrying unknown (but potentially huge) liabilities on their books. And not least, nonclass settlements are to a large extent creatures of contract and agency law that avoid the procedural restrictions of class actions and seem to be virtually unchallengeable and unreviewable.

Why do judges want them? Besides the docket pressures that make settlement preferable to trials in civil litigation across the board, there have always been judges for whom the MDL process is an invitation to push as far as possible toward concluding the cases gathered in this way. ${ }^{19}$ Indeed, there is something in the very dynamics of the MDL process that pushes toward settlement. ${ }^{20}$ Perhaps equally important, the familiarity that the transferee judge acquires in overseeing the pretrial process must give rise to a sense of ownership and a related sense that sending the cases back would put a burden on judges in the courts of original filing, who typically learn little about the cases before they are whisked away to the transferee forum. In the Agent Orange litigation, for example, Judge Pratt as the first presiding judge certified a class and made innumerable rulings on the matter, ${ }^{21}$ but upon his elevation to the Court of Appeals in 1982 the suit was assigned to his colleague Judge Weinstein, who took over the case and immediately scheduled it for trial. $^{22}$ After the Agent Orange settlement, when other Agent Orange cases were filed around the country, it was unthinkable that anyone other than Judge Weinstein should handle them, and the MDL panel

19. See, e.g., Stanley A. Weigel, The Judicial Panel on Multidistrict Litigation, Transferor Courts and Transferee Courts, 78 F.R.D. 575 (1978) (describing expansively the powers of transferee judges, stressing that they can transfer gathered cases under venue statutes and rule on dispositive motions).

20. Richard L. Marcus, Cure-All for an Era of Dispersed Litigation? Toward a Maximalist Use of the Multidistrict Litigation Panel's Transfer Power, 82 TuL. L. REV. 2245, 2288-89 (2008) [hereinafter Marcus, Maximalist Use of MDL's Transfer Power] ("[T]here is at least some reason for institutional uneasiness about more aggressive use of MDL procedures to maximize the judicial system's ability to achieve the most comprehensive settlements.").

21. See In re "Agent Orange" Prod. Liab. Litig., 506 F. Supp. 762 (E.D.N.Y. 1980).

22. See Peter Schuck, Agent Orange on Trial: Mass Toxic Disasters in the Courts 92-122 (1986). See generally Anne Bloom, From Justice to Global Peace: A (Brief) Genealogy of the Class Action Crisis, 39 LOY. L.A. L. REV. 719 (2006) (short and readable description of the Agent Orange litigation). 
transferred them to him as well. ${ }^{23}$ Once a judge becomes expert in a particular controversy, assuming that he has the kinds of skills essential in managing such things, it becomes overwhelmingly likely that similar cases will find their way into his court.

Where do judges get the leverage? It comes at the outset from their power to appoint a Plaintiffs' Management Committee (PMC) or Plaintiffs' Steering Committee (PSC) that is charged with running the litigation for all parties. No statute confers this power, and the only Rule that authorizes judges to take this step is Federal Rule of Civil Procedure (FRCP or Rule) 23(g), which of course applies only in class suits. Nevertheless the power to appoint the PMC exists as a matter of federal common law, traceable to a decision nearly 70 years ago in the MacAlister case, where the Second Circuit ordered consolidation of three shareholder derivative actions, both for pretrial discovery and for trial. ${ }^{24}$ The Second Circuit opinion assured the trial judge that she had the power to appoint "general counsel" for the purpose of "channeling the efforts of counsel along constructive lines," in order to "supervise and coordinate" the cases of the various plaintiffs. ${ }^{25}$ In MDL cases this power is taken for granted, and Judge Fallon in the Vioxx litigation issued an order directing plaintiffs to submit to him nominations for a PSC, from which he made the selections and appointments. ${ }^{26}$

More importantly, appointment to the committees that "run things" for plaintiffs (and sometimes for defendants) concentrates in a small group great power over all the claims, and it is this small group that the transferee judge deals with as the case goes forward. There are essentially no standards that govern the judge in making this selection, although it has been suggested that the process should be regulated after the manner that prevails in securities litigation. ${ }^{27}$ Two consequences ensue from this arrangement: The first is that the judge has extraordinary control over the attorneys running things on the plaintiffs' side. The second is that lawyers for plaintiffs who are not selected for the PMC find themselves on the outs with little to do, little power to affect the

\footnotetext{
23. See Ryan v. Dow Chem. Co., 781 F. Supp. 902, 904 (E.D.N.Y. 1991).

24. MacAlister v. Guterma, 263 F.2d 65, 66 (2d Cir. 1958).

25. Id. at $67-68$.

26. In re Vioxx Prods. Liab. Litig., No. MDL 1657, 2005 WL 850963, at*1 (E.D. La. Apr. 8, 2005). See generally MANUAL FOR COMPLEX LiTIGATION (FOURTH) $§ 10.22$ (2004) (courts in complex cases should "institute procedures under which one or more attorneys are selected and authorized to act on behalf of other counsel and their clients").

27. Charles Silver \& Geoffrey P. Miller, The Quasi-Class Action Method of Managing MultiDistrict Litigations: Problems and a Proposal, 63 VAND. L. REv. 107, 166-70 (2010) (arguing for a system that would appoint lawyers with valuable client inventories on the PMCs in MDL cases).
} 
course of the proceedings, and reduced expectation of compensation, even in the eventuality of a positive outcome. They become bystanders in their own lawsuits. A sidelined lawyer who tries to inject himself in the process, or who resists a settlement favored by the trial judge, would "incur the displeasure" of the judge by such actions. ${ }^{28}$

Consider the degree of control in the hands of the transferee MDL judge: Of course she manages pretrial discovery (or assigns magistrates to do it), but she also exercises considerable control over attorney fees and over settlement. An early attempt by Judge Lord in the intrauterine contraceptive device litigation to inject himself into an agreed settlement was rebuffed by the Eighth Circuit, ${ }^{29}$ but times have changed. In the Zyprexa litigation, for example, Judge Weinstein invoked-really the better term is "invented"- the concept of the "quasi-class action" as the basis for directing special masters to adjust the fee schedules of all claimants in the transferred cases. ${ }^{30}$ Drawing on the same "quasi-class action" concept, Judge Fallon similarly set the fees in the Vioxx litigation, where the settlement agreement made an express provision for the court to "oversee various aspects" of administering the settlement, including determining the amount of "common benefit work." 31 The power of the transferee judge over fees to be paid to counsel as part of a settlement is itself an extraordinary lever that puts enormous power into the hands of the judge. ${ }^{32}$

In the World Trade Center cases, Judge Hellerstein disapproved a proposed settlement because it provided too little compensation to some claimants, and later approved one that increased recovery for them. The

28. Elizabeth Chamblee Burch, Disaggregating, 90 WASH. U. L. REV. 667, 682 (2013).

29. See Gardiner v. A.H. Robins Co., 747 F.2d 1180, 1187-88 (8th Cir. 1984) (Judge Lord wrote "So Ordered" with signature on settlement agreement; reviewing court reverses; this "gratuitous notation" is "prejudicial" to defendant in implying that court "might exercise its powers, including its contempt power" to enforce settlement).

30. See In re Zyprexa Prods. Liab. Litig., 424 F. Supp. 2d 488, 490-92, $496-97$ (E.D.N.Y. 2006) (in this quasi-class action, "a federal court may exercise its supervisory power to ensure that fees are in conformance with codes of ethics and professional responsibility even when a party has not challenged the validity of the fee contract;" the court may also limited fees to $20 \%$ for certain claims with a maximum of $\$ 500$ for costs, and capped other fees at $35 \%$, with room for special master to make upward adjustment to $37.5 \%$ or downward to $30 \%$ in light of circumstances).

31. In re Vioxx Prods. Liab. Litig., 574 F. Supp. 2d 606, 609-10 (E.D. La. 2008) (describing two-step process including examination of "reasonableness of all the contingent fee contracts" and then "allocating a percentage" of fees for common benefit work).

32. See Charles Silver, The Responsibilities of Lead Lawyers and Judges in Multidistrict Litigations, 79 FORDHAM L. REV. 1985, 1991-92 (2011) [hereinafter Silver, Responsibilities of Lead Lawyers and Judges] (little authority addresses the practice of trial judges in setting fees in MDL cases; lawyers in Guidant and Vioxx cases acted opportunistically, using their control over settlement negotiations "to increase the amount of money available for common benefit fees and to prevent disabled lawyers from complaining"). 
parties had agreed on $\$ 575$ million (assuming 95\% participation among claimants, with $\$ 23.4$ million for future claims), but Judge Hellerstein's disapproval led to the addition of $\$ 125$ million plus $\$ 55$ million from an insurance fund, and led as well to a redesigned "settlement grid" setting forth the kinds of relief available for various claimants. ${ }^{33}$ In short, the idea that judges in MDL cases have settlement-approval authority similar to what they have in class action cases under Rule 23(e) seems well on its way to becoming institutionalized. ${ }^{34}$

It is true that the World Trade Center litigation was not an MDL case - Congress created a fund to compensate 9/11 victims, famously administered by Kenneth Feinberg (litigation followed). ${ }^{35}$ The Vioxx litigation, however, was a real MDL mass tort settlement, and the main decision in that case asserts (at least assumes) that the court has power and discretion to examine a proposed settlement in the interest of assuring "fairness," and to disapprove any settlement that is too high or too low or that, in the view of the judge, fails to treat claimants fairly as among themselves. ${ }^{36}$ The settlement approved in the Vioxx cases came after six bellwether trials went forward, one in Texas and five in Louisiana (while the forum in New Orleans was displaced by the effects of Hurricane Katrina). ${ }^{37}$ This settlement was, as Professor Sherman points out, apparently "crafted cooperatively by counsel in both federal

33. Alexandra N. Rothman, Bringing an End to the Trend: Cutting Judicial "Approval" and "Rejection" Out of Non-Class Mass Settlement, 80 Fordham L. ReV. 319, 345-47 (2011) (citing Mireya Navarro, Deal Is Reached on Health Costs of 9/11 Workers, N.Y. TIMES, Mar. 12, 2010, at A1). See generally Robin J. Effron, Event Jurisdiction and Protective Coordination: Lessons from the September 11th Litigation, 81 S. CAL. L. REV. 199 (2008).

34. See FED. R. CIV. P. 23(e) (class claims may be settled, dismissed or compromised "only with the court's approval" after notice, opportunity for hearing, and on finding that it is "fair, reasonable, and adequate").

35. See Kenneth R. Feinberg, What Is Life Worth? 178-91 (Public Affairs 2005) [hereinafter FEINBERG, WHAT Is LIFE WORTH?] (describing 9/11 Fund as "unique response to an unprecedented event," but arguing that public compensation protecting against "unforeseen misfortune" is "an alien notion, inconsistent with liberty," and that our traditions of limited government means that government "shouldn't pay out millions in personal compensation for death or injury as an entitlement" and that doing so undercuts notions of "[i]ndividual responsibility"); Kenneth R. FeinBerg, Who Gets What? 56-62 (Public Affairs 2012) [hereinafter FeinBerg, WHO GETS WHAT?] (describing author's 33 months as special master and adhering to view that $9 / 11$ Fund was "sound public policy," but also that it is "inconsistent with an American political philosophy characterized by equal protection" and "egalitarianism and fair play" to provide public compensation for a limited group, each receiving a different amount).

36. See In re Vioxx, 574 F. Supp. 2d at 610, 613-14 (describing two-step process including examination of "reasonableness of all the contingent fee contracts" and then "allocating a percentage" of fees for common benefit work).

37. Eldon E. Fallon, Jeremy T. Grabill \& Robert Pitard Wynne, Bellwether Trials in Multidistrict Litigation, 82 TUL. L. REv. 2323, 2335-37 (2008) [hereinafter Fallon, Grabill \& Wynne, Bellwether Trials] (describing these trials). 
and state courts, and blessed and overseen in execution by the MDL court." ${ }^{38}$ Not surprisingly, Judge Fallon had urged the parties to begin settlement negotiations, ${ }^{39}$ and he took the unusual step of including with him, on the bench in a status conference in which the settlement was presented, the judges presiding over Vioxx cases in state court that had not been gathered in federal court. ${ }^{40}$ It is clear from the remarks made at the time that the judges were pleased with the settlement. ${ }^{41}$

Why do lawyers for plaintiffs want MDL aggregate mass tort settlements? Obviously there is a financial incentive to serve on the PMC if, as usually happens, the judge makes upward adjustments in the fees recoverable for doing what gets called "common benefit" work in the likely event of a settlement. Like the custom of appointing the PMC, we have what amounts to almost an ancient pedigree for the idea that a judge can tax a settlement to ensure that lawyers conducting discovery in gathered cases are paid for their extra work, and that inactive lawyers don't recover "windfalls" for doing very little. Almost forty years ago the Ninth Circuit in the Vincent case held that a judge can tax the settlement share of clients in consolidated litigation to pay the fees of those court-appointed lawyers who do the lion's share of the pretrial work, ${ }^{42}$ and modern authority confirms the judge's authority to tax a settlement that a defendant in a consolidated case makes with parallel claimants in nongathered cases (often pending in state court in distant fora) by ordering defendant to withhold from the settlements an amount corresponding to what the court thinks is the plaintiffs' fair share of the common benefit work. ${ }^{43}$ Service on such a committee virtually assures significant recovery of attorney fees when the case settles.

Appointment to the PMC is big business. ${ }^{44}$ Typically its work is

38. Sherman, supra note 4, at 2223.

39. In re Vioxx Prods. Liab. Litig., No. MDL 1657, 2010 WL 724084, at *2 (E.D. La. Feb. 18, 2010) (describing conference in which presiding Judge Fallon and state judges from Texas, New Jersey, and California "expressed the view that it was timely for the parties to begin serious settlement discussions").

40. Grabill, supra note 11, at 142-45.

41. See id. at 145, $145 \mathrm{nn} .102-03$ (2012) (citing to the "Transcript of Status Conference," which reflected the presence of Judges Fallon, Carol Higbee of New Jersey Superior Court and Victoria Chaney of California Superior Court in Los Angeles; in which Judge Fallon comments that "a large portion of the credit for resolving litigation belongs to the lawyer").

42. See Vincent v. Hughes Air West, Inc., 557 F.2d 759, 770-73 (9th Cir. 1977).

43. See In re Avandia Mktg., Sales Practices \& Prods. Liab. Litig., 617 F. App’x 136, 141-44 (3d Cir. 2015) (federal court in Eastern District of Pennsylvania could tax defendant in MDL case by ordering it to withhold $7 \%$ from California state court settlement in related litigation to pay common benefit fund).

44. They go under a variety of names-PMCs (Plaintiffs' Management Committees); PECs (Plaintiffs' Executive Committees); PPCs (Plaintiffs' Planning Committees). 
extensive and must be financed, so appointment to a PMC doesn't come cheap. Reportedly judges appoint such committees by selecting "top-tier attorneys" who are expected to invest hundreds of thousands of dollars in these undertakings. ${ }^{45}$ Appointment can be not only expensive, but risky: Judges sometimes appoint lawyers for fixed terms, so their performance can be assessed and underperformers can be replaced, a circumstance that cannot help but make lawyers hearken closely to the judge's preferences. $^{46}$ A commentator who surveyed pending MDL mass tort suits in 2013 concluded that repeat players among the plaintiff's bar garnered almost two thirds of controlling positions in such committees. ${ }^{47}$ Expenses and attorney fees are at least sometimes recoverable from this fund as the litigation proceeds, ${ }^{48}$ and the rewards for common benefit work can be considerable. ${ }^{49}$

Why do defendants want such MDL aggregate mass tort settlements? One modern study contends that defendants are willing to pay a premium - actually more to settle "the whole batch" of cases brought against them than they would pay for all the individual claims if they settled one by one-for a "global" MDL settlement (one that covers essentially all potential claimants). ${ }^{50}$ This study focused on a comparison between recoveries awarded under the auspices of the Gulf Coast Claims Facility (GCCF) set up and administered by Kenneth Feinberg and those awarded to claimants in the MDL settlement. Under his leadership, GCCF distributed more than $\$ 6.2$ billion to 220,000 individual claimants in 18 months of operation, paying out more than $\$ 840$ million in its second month-extraordinary feats. ${ }^{51}$ A later audit of the program,

45. See Dodge, Facilitative Judging, supra note 10, at 362.

46. See In re Avandia Mktg., Sales Practices \& Prods. Liab. Litig., 617 F. App’x 136, 139 n.2 (3d Cir. 2015) (declining to "renew" attorney membership in plaintiffs' steering group and appointing new plaintiffs' advisory committee).

47. Elizabeth Chamblee Burch, Judging Multidistrict Litigation, 90 N.Y.U. L. REV. 71, 96101 (2015) (suggesting that this tendency may encourage "uniform" and "less innovative" thinking and collusive settlements).

48. For description of the process, see generally Leonard A. Davis \& Philip A. Garrett, Case Time and Cost Management for Plaintiffs in Multidistrict Litigation, 74 LA. L. REV. 483 (2014); Dodge, Facilitative Judging, supra note 10, at 356-60.

49. See In re Oral Sodium Phosphate Sol.-Based Prods. Liab. Action, No. MDL 2066, 2010 WL 5058454, at *2-5 (N.D. Ohio Dec. 6, 2010) (reporting on common fund fee-plus-expense awards ranging between zero or a few thousand dollars to $\$ 1.3$ million).

50. Samuel Issacharoff \& D. Theodore Rave, The BP Oil Spill Settlement and the Paradox of Public Litigation, 74 LA. L. REV. 397, 413-14 (2014) (arguing that settling claimants in BP Oil Spill MDL fared better than claimants paid through Gulf Coast Claims Facility, despite higher transaction costs in MDL proceedings; defendants will pay a "peace premium" for greater finality and firm cutoff date).

51. See FeinBerg, Who Gets What?, supra note 35, at 125-204 (describing author's two years as administrator of GCCF). 
conducted at the request of the Department of Justice, concluded that the GCCF "operated in an extremely time-sensitive, challenging and dynamic environment," and that in general it "consistently applied its protocols and methodologies in processing claims." N2 Nevertheless lawsuits arising out of the Gulf oil spill went forward on a parallel track, and these were gathered in the MDL process in the Eastern District of Louisiana, leading finally to a settlement in the amount of approximately $\$ 18.7$ billion. $^{53}$ Comparing recoveries under this settlement and the GCCF payouts led to the conclusion that MDL settlements might actually pay claimants more - a kind of global peace premium that some defendants are willing to pay.

There may be another reason why defendants find MDL mass tort settlements attractive: They hold out some possibility of staving off attempts to certify class litigation. In the Aqua Dots case the Seventh Circuit held that claimants seeking to represent a class under FRCP 23(b)(3) failed the adequate representation requirement where the manufacturer had instituted a voluntary product recall campaign. ${ }^{54}$ In this setting, pursuing class litigation amounted to an attempt to obtain "a remedy that most buyers already have received, and that remains available." A standard bearer who proposes to incur "high transaction costs" for notice and attorney fees to obtain a refund that "already is on offer" is not adequately protecting the interests of the class. ${ }^{56}$ While it remains true that many suits gathered in the MDL process do later become certified as class suits, the prospect of quicker and easier resolution in the MDL settlement process holds some promise of blocking certification. ${ }^{57}$

52. BDO Consulting, IndePendent Evaluation of the Gulf Coast Claims Facility EXECUTIVE SUMMARY 2 (2012), http://www.justice.gov/iso/opa/resources/697201241917226179477.pdf. The audit concluded that GCCF made errors affecting about one percent of claims and one percent of payouts. See id. at 6-8. It ordered additional payments of $\$ 64$ million to some 7,300 claimants. See id. at 2, 7.

53. Margaret Cronin Fisk \& Laurel Brubaker Calkins, BP's \$18.7 Billion Oil-Spill Deal Still Leaves Lesser Messes, BLOOMBERG (July 2, 2015, 7:01 PM), http://www.bloomberg.com/news/articles/2015-07-03/bp-s-18-7-billion-oil-spill-deal-still-leaveslesser-messes.

54. See In re Aqua Dots Prods. Liab. Litig., 654 F.3d 748, 751-52 (7th Cir. 2011).

55. Id. at 752 .

56. Id. (error to rely on the superiority clause in FRCP 23(b)(3) because recall is not another method of adjudicating; the adequate representation requirement supports what trial judge did).

57. See, e.g., Waller v. Hewlett-Packard Co., 295 F.R.D. 472, 482, $488-90$ (S.D. Cal. 2013) (denying class certification in consumer fraud case against maker of external backup device; the availability of software updates means that the class suit would not satisfy the superiority or the adequate representation requirements). 


\section{B. What's Wrong with MDL Product Liability Settlements?}

Differences of opinion among scholars are commonplace, but the disagreement about MDL settlements goes not to details but to the substance and the very legitimacy of the undertaking. Critics - and let us call them proceduralists - stress that MDL proceedings go forward without legal authority, without standards, and without adversary testing, and they argue that transferring control from individual clients and lawyers to PMCs violates due process and raises larger questions of democratic legitimacy. Defenders - let us call them aggregationistsargue that the process produces better outcomes than we could get otherwise, that individual rights are adequately protected, and that there is little or no difference between the representative character of individual suits and the representative character of MDL settlement processes.

\section{These Settlements Lack a Basis in Law}

It is a remarkable fact that MDL mass settlements go forward today without any basis in statute or rule. The MDL statute does not contemplate final disposition of MDL cases by settlement in the transferee forum. Instead, it mandates return of gathered cases to the fora of original filing, and the Lexecon case concluded that the statute means what it says - that the authority of the transferee court is limited to pretrial matters, and it cannot retain jurisdiction to try gathered cases. ${ }^{58}$ In other words, these judicially-encouraged settlements happen in courts that lack authority to try the cases they are settling. In striking contrast are class action settlements achieved under Rule 23. This provision sets out criteria designed to assure fairness and confers unusual and extraordinary power on courts, and these are surveyed further below. The point to be made here is that the Rule 23 safeguards, and the extraordinary powers that Rule 23 authorizes courts to exercise, apply to class suits and not to MDL litigation.

What we have, then, is a legal environment in which black letter law (FRCP 23) speaks directly to situations closely resembling those that lead to MDL gathering. This law sets limits, establishes criteria, and authorizes a degree of judicial supervision and control that is very much out of the ordinary. Into this environment has come MDL mass tort

58. See 28 U.S.C. § 1407(a) (2012) (transferred cases "shall be remanded" by the JPML "at or before the conclusion" of pretrial proceedings "to the district from which [they were] transferred"); Lexecon, Inc. v. Milberg Weiss Bershad Hynes \& Lerach, 523 U.S. 26, 40-41 (1998). 
consolidation that operates free of those limits, ignores those criteria, and employs the same extraordinary judicial power. As Professor Mullinex argues, the attempt effectively to invent judicial power to do what MDL settlement courts are doing, by resort to the term "quasi-class action," is a thin reed on which to pin the legitimacy of what is really a new mechanism. ${ }^{59}$ There is no hint of an organic or gradual growth of doctrine to meet a new situation. Instead we see an implanting of a new term linked to the court's "general equitable powers." "quasi-class action" concept in the Zyprexa cases, Judge Weinstein cited three things: Rule 23, the American Law Institute (ALI) Complex Litigation Project (there is "a strong interest in allowing" MDL transferee forum to manage gathered cases "in the way that it believes will serve best the interests of justice and efficiency") and the Manual for Complex Litigation (absence of precedent or statutes or rules "should not foreclose innovation and creativity"). ${ }^{61}$ What these references really show is the absence of any true foundation for the "quasi-class action." They certainly do not ground the idea in actual doctrine.

Worse, this development reflects a conscious effort, by lawyers and courts alike, to sidestep the safeguards in the one provision in the Rules that seems to address the situation confronting courts and litigants in the setting of aggregate product claims - namely, Rule 23, and decisions implementing this provision. Chief among these are Amchem $^{62}$ and Ortiz. ${ }^{63}$ In Amchem, the Court rejected a class settlement, worked out in advance, largely because of inadequate representation of persons suffering disparate kinds of injury over a long time, and because of the difficulty (perhaps impossibility) of notifying asymptomatic persons that they are about to be bound by settlement of a suit they have no reason to know about. ${ }^{64}$ In Ortiz, the Court threw out a supposed limited fund class settlement because there was in fact no limited fund, and because interests of absent claimants were not adequately represented for reasons

59. Mullenix, Dubious Doctrines, supra note 12, at 391-94 (arguing that quasi-class action is "a phantasm" mostly invented by Judge Weinstein in Zyprexa cases, as an "attempt to accomplish by label what is otherwise prohibited by doctrine").

60. In re Zyprexa Prods. Liab. Litig., 233 F.R.D. 122, 122-23 (E.D.N.Y. 2006); see also In re Zyprexa Prods. Liab. Litig., 433 F. Supp. 2d 268, 271 (E.D.N.Y. 2006).

61. In re Zyprexa, 433 F. Supp. $2 \mathrm{~d}$ at 271 (first citing FED. R. CIV. P. 23; then quoting AM. Law Inst., COMPlex Litigation Project app. B, § 6 cmt. c at 819 (Council Draft No. 4 1992); and then quoting MANUAL FOR COMPLEX LiTIGATION (FOURTH) $\S 22.1$ (2004)); see also In re Zyprexa, 233 F.R.D. at 122-23 ("quasi-class action, subject to general equitable powers of the courts").

62. Amchem Prods., Inc. v. Windsor, 521 U.S. 591 (1997).

63. Ortiz v. Fibreboard Corp., 527 U.S. 815 (1999).

64. See Amchem, 521 U.S. at 622-28. 
similar to those in Amchem. ${ }^{65}$ In both Amchem and Ortiz, moreover, claimants' lawyers had the chutzpah to exempt from the settlements other cases they were handling ("inventory" claims), in effect waving a red flag that betokened favoritism and self-dealing. ${ }^{66}$ Those claims were exempted from the settlements precisely because the lawyers were negotiating better deals for their "other" clients (and likely higher fees per dollar of recovery), which raises serious ethical questions, to put it mildly ${ }^{67}$ We should also take into consideration the decisions in WalMart, which strengthened the common question requirement, ${ }^{68}$ and the series of appellate decisions that "frontload" class certification requirements. ${ }^{69}$ These decisions direct courts carefully to apply class action criteria on the basis of evidentiary hearings on the shape of any trial and the role of common questions. ${ }^{70}$ They also insist on careful treatment of choice-of-law issues in cases governed by state law, ${ }^{71}$ and they point to the conclusion that the Daubert standard for expert testimony applies in certification hearings. ${ }^{72}$

Even these observations do not adequately describe problems in the legitimacy of MDL settlements. Arguably court judgments on these settlements violate established legal principles. Some of the Amchem principles appear, after all, not only to derive from Rule 23, but also to express constitutional standards. The great stress, for example, on differences among claimants, and the suggestion that adequate

65. See Ortiz, 527 U.S. at 842-48 (record fails to demonstrate existence of limited fund).

66. See Amchem, 521 U.S. at 600-01, 606-07; Ortiz, 527 U.S. at 819. The Amchem and Ortiz decisions discuss the exclusion of inventory claims by claimants represented by counsel for the plaintiff class from settlements of the class claims.

67. See Model Rules of Prof'L CONDuct r. 1.7 (AM. BAR ASS'N 2016) (barring representation raising "concurrent conflict of interest," as occurs if representing one client is "directly adverse to another" or there is "a significant risk" that representation of a client "will be materially limited by the lawyer's responsibilities to another client," but allowing such conflict if lawyer "reasonably believes" that he can "provide competent and diligent representation" to each client).

68. See Wal-Mart Stores, Inc. v. Dukes, 564 U.S. 338, 349-59 (2011).

69. See Richard D. Freer, Front-Loading, Avoidance, and Other Features of the Recent Supreme Court Class Action Jurisprudence, 48 AKRON L. REV. 721, 721-24 (2015).

70. See, e.g., In re Hydrogen Peroxide Antitrust Litig., 552 F.3d 305, 320-24 (3d Cir. 2008) (class certification requires findings by a preponderance of the evidence that every requirement of FRCP 23 has been met, and a mere "threshold showing" does not suffice).

71. See, e.g., Castano v. Am. Tobacco Co., 84 F.3d 734, 740-50 (5th Cir. 1996) (rejecting nationwide class treatment of claims for nicotine dependence; trial court did not consider effect of variations in state law on predominance requirement).

72. See Wal-Mart, 564 U.S. at 353-55 (expressing "doubt" at district court's conclusion that Daubert doesn't apply in certification hearings); In re Blood Reagents Antitrust Litig., 783 F.3d 183, 187 (3d Cir. 2015) ("[A] plaintiff cannot rely on challenged expert testimony, when critical to class certification, to demonstrate conformity with Rule 23 unless the plaintiff also demonstrates, and the trial court finds, that the expert testimony satisfies the standard set out in Daubert."). 
representation requires at least the appointment of separate standard bearers and counsel for asymptomatic claimants, appears to implement due process. $^{73}$ Hansberry equates adequate representation with due process, and the Court in its decision in Shutts reiterated that due process requires adequate representation. ${ }^{74}$

Amchem also alludes to the importance of an adversary proceeding, in which counsel for claimants can credibly suggest that the alternative to settlement is trial. ${ }^{75}$ In offering that comment, the Court rejected the argument that appraising the adequacy of settlement could substitute for applying the criteria for class certification. ${ }^{76}$ Of course that is exactly what happens in MDL settlements-consideration of fairness and adequacy of settlement displaces other considerations. The comment in Amchem could be understood as insisting on a certain reading of Rule 23, merely repeating a point made above (MDL procedure lacks a foundation in law). But Martin Redish has argued forcefully that settlement class suits should be disallowed because they do not satisfy the case or controversy requirement: Part of his argument turns on the fact that lawyers approach a court only when they have already agreed that there will be no trial (no adversarial contest). ${ }^{77}$ MDL settlements are different because lawsuits have been filed, and could go forward after discovery is completed. But that is not what happens, and much of what is missing in settlement classes is also missing in MDL cases: Here too it is possible to say, as Professor Redish does say, that judgment on an MDL settlement threatens the interests of the absent claimants by binding them to a judgment "rendered without the protections and incentives that traditionally accompany an adversarial suit." 78

73. See Georgine v. Amchem Prods., Inc., 83 F.3d 610, 626, 634-35 (3d Cir. 1996) (claimants were exposed to "different asbestos-containing products, for different amounts of time, in different ways, and over different periods," and some claimants "suffer no physical injury or have only asymptomatic pleural changes, while others suffer from lung cancer, disabling asbestosis, or from mesothelioma," and "[e]ach has a different history of cigarette smoking."); see also Amchem Prods., Inc. v. Windsor, 521 U.S. 591, 624 (1997) (quoting Georgine, 83 F.3d at 626).

74. Phillips Petroleum Co. v. Shutts, 472 U.S. 797, 812 (1985) (citing Hansberry v. Lee, 311 U.S. 32, 42-43, 45 (1940)) (beyond notice and opportunity to be heard and opt out, due process "requires that the named plaintiff at all times adequately represent the interests of the absent class members").

75. See Amchem, 521 U.S. at 621.

76. See id. ("[I]f a fairness inquiry [into the adequacy of settlement] under Rule 23(e) controlled certification, eclipsing Rule 23(a) and (b), and permitting class designation despite the impossibility of litigation, both class counsel and court would be disarmed" because counsel "could not use the threat of litigation to press for a better offer.").

77. See generally Martin H. Redish, Wholesale Justice 177-78 (2009).

78. Id. at 210 . 


\section{They Turn on Made-Up Rights}

We grew up in our legal education and careers understanding that ours is a nation of individual rights. In different settings the Supreme Court has spoken often of civil claims being "choses in action" that are property protected by the Fourteenth Amendment's due process clause, most famously in the decisions in Mullane ${ }^{79}$ and Shutts. ${ }^{80}$ It should go without saying, but in any event others have said it, that the holder of such rights should be able to choose whether to assert them or not, ${ }^{81}$ whether to hire a lawyer or not, whether to sue or not, to select the time and place (within limits), and whether to settle or not. ${ }^{82}$ At least equally important, the holder of such rights should be assured that she (or at least her representative) can participate actively in any process in which such rights are determined. ${ }^{83}$

In facing such objections, aggregationists make two moves. First, they reconceptualize rights in group terms. At least some rightsapparently those arising from mass torts that happen every day-are "owned" by "classes" or "groups" of people, not by individuals, and in effect the "party" in mass tort cases is already the "class" or "group," not the individual. ${ }^{84}$ There is no basis in law for this move and it isn't

79. Mullane v. Cent. Hanover Bank \& Trust Co., 339 U.S. 306 (1950).

80. Phillips Petroleum Co. v. Shutts, 472 U.S. 797 (1985); see also Richards v. Jefferson Cty., 517 U.S. 793, 804 (1996); United States v. Belmont, 301 U.S. 324, 333-35 (1937) (Stone, J., concurring); Wheeling Steel Corp. v. Fox, 298 U.S. 193, 209-13 (1936); Endicott-Johnson Corp. v. Encyclopedia Press, Inc., 266 U.S. 285, 289 (1924); Ferry v. Spokane, P. \& S. Ry. Co., 258 U.S. 314, 318 (1922); City of Cincinnati v. Louisville \& Nashville R.R. Co., 223 U.S. 390, 400 (1912); Legal Tender Cases, 79 U.S. (12 Wall.) 457, 506 (1870).

81. See Benjamin C. Zipursky, Rights, Wrongs, and Recourse in the Law of Torts, 51 VAND. L. REV. 1, 80 (1998) (advancing recourse theory of rights, under which "the state does not judge that certain defendants ought to pay certain amounts to plaintiffs," but instead "the state accedes to, and enforces, a plaintiff's demand that the state compel defendant to pay her a certain amount").

82. See, e.g., Martin H. Redish \& Julie M. Karaba, One Size Doesn't Fit All: Multidistrict Litigation, Due Process, and the Dangers of Procedural Collectivism, 95 B.U. L. REV. 109, 113-14 (2015) (whether viewed from perspective of paternalism or personal autonomy, due process is violated by a procedure that selects counsel and representative parties without "opportunity for a transparent, adversary-based adjudication" of adequacy and accountability).

83. See, e.g., Elizabeth Chamblee Burch, Procedural Justice in Nonclass Aggregation, 44 WAKE FOREST L. REV. 1, 37-43 (2009) (describing importance of participation in achieving accuracy, legitimacy, and claimant satisfaction).

84. See Samuel Issacharoff, Preclusion, Due Process, and the Right to Opt out of Class Actions, 77 Notre Dame L. REV. 1057, 1060 (2002) (classes "take on the form of an 'entity,' to borrow Professor Shapiro's term," and it is hard to view due process in terms of whether "an individual right of action may be recreated" in class suits); David L. Shapiro, Class Actions: The Class as Party and Client, 73 Notre DAME L. REV. 913, 938-42 (1998) (endorsing entity model in mass tort cases involving personal injuries, which has important implications for role of judge and choice of law); Edward H. Cooper, Rule 23: Challenges to the Rulemaking Process, 71 N.Y.U. L. REV. 13, 29 (1996) ("[I]maginative use of the entity concept might even support a more rational 
plausible to assert that individual rights turn into group rights simply because there are many violations. The shift in vocabulary is like Sartre's "magical transformations," in which human emotions transform the world to accommodate deep-felt personal needs and wishes, ${ }^{85}$ only the purpose here is to change the world for everyone, which seems a different thing altogether. In any event, the shift should point the way not from individual suits to MDL transfers and settlement, but from individual suits to class actions, which require a showing of necessity and includes at least some protections for individual claimants.

Second, aggregationists argue that there isn't much difference between aggregate litigation and individual suits handled by lawyerspecialists. In our world, googling things like "hip replacement claims" leads to websites of law firms, and popups asking "May We Help You?" with offers of free consultation and toll-free phone numbers. In short, people with claims arising from use of drugs or products or from medical treatments can locate specialists in minutes. These are often large firms with many similar clients. In a wide-ranging development of this argument, Professors Issacharoff and Witt say the origins of modern tort law were in "the machine age," when the Industrial Revolution of the nineteenth century saw more personal injury cases, often suits against "large industrial concerns" for workplace injuries, leading to the development of both specialized defense bars and plaintiff bars. ${ }^{86}$ By the late twentieth century, they suggest, market forces and the benefits of economies of scale led to "concentration of market share on both the plaintiff and defense sides," and to ever more settlements and fewer trials, in which "routinized negotiations between established representatives" led to settlements based on "grid structures for the actuarial treatment of accident claims." 87

We should acknowledge that choosing such a firm can make good sense: Economies of scale mean that a specialist can bring claims quickly and efficiently, and can pursue the matter with knowledge and the benefits of evidence developed in representing others. Even proceduralists who are skeptical about MDL mass tort settlements concede that rational litigants might prefer to be part of a large

approach to choice of law [in class suits].").

85. See Norman K. Denzin, On Understanding Emotion 45-47 (1984) (describing Sartre's view, under which an emotion is "a transformation of the world" that occurs when "paths in the world are blocked, yet action must go forward, either through necessity or because of desire," in which "the person attempts to change the world by changing his consciousness").

86. Samuel Issacharoff \& John Fabian Witt, The Inevitability of Aggregate Settlement: An Institutional Account of American Tort Law, 57 VAND. L. REV. 1571, 1579-80, 1611 (2004).

87. Id. at 1618 . 
"inventory" of claimants. ${ }^{88}$ Indeed, probably many clients who wind up in MDL proceedings knew from the beginning that their claims would be consolidated with others, as specialist firms advertise the advantages of combined claims, usually referring to class actions (more familiar to the public than MDL). ${ }^{89}$

In response to this argument, suffice it to say that it is one thing to be a single client among many with similar claims represented by a single firm, and quite another thing to be represented by lawyers who are sidelined in the MDL process. Most lawyers in the MDL setting have no control over the progress of the suit, and can do effectively nothing for their clients except monitor what is going on, often in a distant forum. And there is a considerable gulf between a situation in which one firm represents scores (even hundreds or thousands) of clients with similar claims and a situation in which lawyers represent tens of thousands of clients with whom they (or their firms) have had no contact whatsoever. A small and localized bureaucracy is easier to deal with than a vast and distant bureaucracy.

\section{They Conform to No Standards}

Rule 23 permits certification of classes only if multiple criteria are satisfied. In the usual mass tort setting, Rule 23 requires adequate representation, typicality, predominance of common questions, manageability, and superiority over individual litigation. Equally important, Rule 23 imposes on courts to implement special safeguards, which obligate and empower judges to pass on the question whether class treatment is proper (certification provision), to oversee adequacy of

88. Howard M. Erichson, Beyond the Class Action: Lawyer Loyalty and Client Autonomy in Non-Class Collective Representation, 2003 U. CHI. LegAL F. 519, 538, 545, 550 (2003) [hereinafter Erichson, Beyond the Class Action] ("firms have found niches and gathered large numbers of clients with related claims," and "most clients in mass litigation settings prefer the strength of collective representation," and willingly give up autonomy to achieve economies of scale); Bruce Hay \& David Rosenberg, "Sweetheart" and "Blackmail" Settlements in Class Actions: Reality and Remedy, 75 NOTRE DAME L. REV. 1377, 1380 n.8 (2000) ("[t]he vote in the marketplace is decidedly against the individual benefits of so-called "litigant autonomy"').

89. See, e.g., Class Action Lawsuits, SEEGERWeISS LLP, http://www.seegerweiss.com/classactions/ (last visited Jan. 2, 2017) (webpage for New York City law firm) ("For many of the victims involved in class action litigation, this is the only meaningful way to attempt to address fraud, widespread discrimination or other legal violations. You can take the case of any class action litigation cases against major car companies or major tobacco companies in the past to understand how a class action litigation can help."); Firm Overview and History, LEVIN, FISHBEIN, SEDRAN \& BERMAN, http://www.lfsblaw.com/overview/ (last visited Jan. 2, 2017) (webpage for Philadelphia law firm explaining how partners in the firm serve on guiding committees in major product cases, "often involving parallel state and federal court proceedings or Multidistrict Litigation in federal court," and they do so "without losing contact with the individual client"). 
representation by selecting appropriate counsel and monitor performance as the case progresses, to create subclasses when necessary, and to accord or limit class treatment. Rule 23 contains notice provisions that assure absent class members that they can intervene or (in most money damage suits) opt-out of the suit altogether. Rule 23 entitles them to be heard in settlement hearings. And Rule 23 creates opportunities for interlocutory appeal, particularly at the certification stage.

Many commentators have argued that even the Rule 23 criteria and safeguards are inadequate to assure accuracy and fairness. Some of these critics argue that Rule 23 needs a complete reworking with the idea of improving the operation of what is basically a good mechanism. ${ }^{90}$ Others would change it but think the present Rule is better than the unstructured MDL procedures. ${ }^{91}$ Yet others think the concept of class suits is undemocratic and, particularly in the setting of litigation whose goal is almost always settlement and not trial, an unconstitutional distortion of the judicial process. ${ }^{92}$ Indeed, objecting parties approached these issues in the Amchem case when they raised questions about justiciability and standing, but the reviewing courts did not address them. ${ }^{93}$

Regardless how one comes out on these questions, it is clear that Rule 23 accomplishes three things: It sets standards against which the performance of lawyers and courts can be assessed; it addresses real concerns; it assures the possibility of review that does not merely defer to judicial discretion. As one able commentator has put it, MDL procedures have "stripped away protections afforded by class action requirements," enabling participants to "settle complex cases largely unconstrained by law," creating the "perfect means for negotiating backroom deals that carry an aura of judicial legitimacy, liberated from the constraints of the formal class action rule." 94

There is an even more fundamental sense in which MDL judgments on settlements in mass tort cases lack a legal basis: They rest on the law

90. See, e.g., Robert G. Bone, Walking the Class Action Maze: Toward a More Functional Rule 23, 46 U. MiCH. J.L. REFORM 1097 (2013).

91. See, e.g., Linda S. Mullenix, Ending Class Actions as We Know Them: Rethinking the American Class Action, 64 EMORY L.J. 399 (2014).

92. See Redish \& Karaba, supra note 82, at 131-51.

93. Amchem Prods., Inc. v. Windsor, 521 U.S. 591, 612-13 (1997) (declining to address standing, justiciability, or jurisdiction, following "the path taken by the Court of Appeals" in disposing of the case by applying class certification criteria).

94. Linda S. Mullenix, Aggregate Litigation and the Death of Democratic Dispute Resolution, 107 Nw. U. L. REV. 511, 553-54 (2013) [hereinafter Mullenix, Aggregate Litigation]. 
of no particular state, ${ }^{95}$ even if the claims advanced in the thousands of complaints gathered in this mechanism rest on state law and get into federal court on the basis of diversity jurisdiction, now expanded by Class Action Fairness Act (CAFA) and the Mass Accident statutes. ${ }^{96}$ The Court in Shutts announced that considerations of manageability do not justify applying forum law in a class suit, ${ }^{97}$ and the Court commented in Amchem that federal courts "lack[] authority to replace state tort systems with a national toxic tort compensation regime." ${ }^{98}$ Aggregationists flout these principles, and courts approving MDL settlements in mass tort cases seem to think they can be "fair and adequate" without considering the substantive laws that would apply to such claims if they were litigated in the courts of original filing. Often this appraisal rests on "bellwether" trials conducted in the transferee forum and applying variously the laws that might apply to the selected samples if they had been tried where originally filed, as happened in the Vioxx cases in which bellwether trials went forward in Louisiana (five trials) and Texas (one trial) while applying the laws of Florida, South Carolina, Kentucky, Utah, and Tennessee. ${ }^{99}$

The ALI called for a federal choice-of-law rule more than 50 years ago, ${ }^{100}$ but it never happened. Probably this step would require congressional action, as decisions in the Erie line consistently hold that federal courts must apply state choice-of-law rules in diversity cases. ${ }^{101}$ Commentators have long urged the creation of federal choice-of-law rules, whether by common law evolution or congressional enactment, and one commentator even argues that the Constitution requires such rules. ${ }^{102}$ Clearly Congress has not taken this step, although courts in

95. But see Richard L. Marcus, They Can't Do That, Can They? Tort Reform via Rule 23, 80 CORNELL L. REV. 858, 904-07 (1995) (expressing cautious optimism that class settlements can affect tort reform, where courts can hope in exceptional cases to deliver compensation to claimants who otherwise would go without recovery).

96. The main provision of the Class Action Fairness Act is codified in 28 U.S.C. $\S 1332(\mathrm{~d})(1)$ (2012); the main provision in the Mass Claims Act is codified in 28 U.S.C. $\S 1369$ (2012).

97. Phillips Petroleum Co. v. Shutts, 472 U.S. 797, 821-23 (1985).

98. Amchem, 521 U.S. at 599.

99. Fallon, Grabill \& Wynne, Bellwether Trials, supra note 37, at 2335-36.

100. Am. LAw InST., STUDY OF THE Division OF JURISDICTION BETWEEN STATE AND FEDERAL COURTS $\S \S 2371,2374$ (1969) (proposing statutory change to enable federal courts to apply federal choice-of-law rules in certain removed diversity cases).

101. Atl. Marine Constr. Co. v. U.S. Dist. Court for the W. Dist. of Tex., 134 S. Ct. 568, 582 (2013) (acknowledging principle); Ferens v. John Deere Co., 494 U.S. 516, 532 (1990); Shutts, 472 U.S. at 820-23; Day \& Zimmerman, Inc. v. Challoner, 423 U.S. 3, 4 (1975); Klaxon Co. v. Stentor Elec. Mfg. Co., 313 U.S. 487, 494-97 (1941).

102. See Douglas Laycock, Equal Citizens of Equal and Territorial States: The Constitutional Foundations of Choice of Law, 92 CoLUM. L. REV. 249 (1992) (arguing that Constitution requires 
class suits with nationwide reach have sometimes applied the law of the place of defendant's conduct to all claims in order to facilitate class treatment, ${ }^{103}$ and one commentator has argued that CAFA authorizes federal courts to begin the task of formulating federal choice-of-law rules for such suits. ${ }^{104}$ Patrick Woolley has replied persuasively, however, that that even if Congress or federal courts could federalize choice-of-law rules, doing so would profoundly alter the vision of federalism developed by Erie and the many decisions that followed. ${ }^{105}$

In any event, a federal choice-of-law rule would not solve anything unless it pointed toward a single state's law, as the Institute realized in 1993 in its recommendations on handling complex litigation. ${ }^{106}$ Can it possibly make sense to retain a system in which state law supplies substantive standards that apply to product liability and state courts apply their own choice-of-law rules, but federal courts apply a federal choiceof-law rule in selecting a single state's substantive law as the rule of decision? Can it possibly make sense to apply the law of one state to separate transactions, related only by the fact that they involve some act that is repeated in different places and times, or some product or service that is provided in different places and times, on the theory that they are matters of "national" concern? ${ }^{107}$ For almost eighty years we have understood that there cannot be one justice in federal courts and another in state courts - one law applied in diversity cases, and another applied in the same litigation in state courts. What would come of that idea if we

both federal and state courts to apply federal choice-of-law rules, and absent congressional action federal courts should fashion such rules).

103. See Russell J. Weintraub, Commentary on the Conflict of Laws 492 (6th ed. 2010) (commenting that it is "easiest to justify" this result under conventional approaches to choice of law if the law thus chosen would give each class member at least as much as the law of his or her domicile).

104. Samuel Issacharoff, Settled Expectations in a World of Unsettled Law: Choice of Law After the Class Action Fairness Act, 106 ColuM. L. REV. 1839, 1839 (2006) (arguing that federal courts after CAFA should apply, absent further congressional action, the laws of defendant's home state when claims arise from "mass-produced goods entering the stream of commerce with no preset purchaser or destination").

105. See Patrick Woolley, Erie and Choice of Law After the Class Action Fairness Act, 80 TuL. L. REV. 1723, 1757-63 (2006) (federal choice-of-law rule would take us back to Swift v. Tyson, 41 U.S. (16 Pet.) 1 (1842), where diversity jurisdiction carried authority to make the law being applied).

106. AM. LAW. INST., COMPLEX LITIGATION: STATUTORY RECOMMENDATIONS AND ANALYSIS With REPORTER'S STUDY: A MODEL SYSTEM FOR STATE-TO-STATE TRANSFER AND CONSOLIDATION 321-22 (1994) (setting out criteria to be applied "with the objective of applying, to the extent feasible, a single state's law," and referencing the places of injury, conduct, and domiciles of claimants and defendants as relevant elements in choosing).

107. See Larry Kramer, Choice of Law in Complex Litigation, 71 N.Y.U. L. REV. 547, 578 (1996) ("I would have thought that the more 'national' the case, the less appropriate it is for any single state's standard to govern."). 
established a federal choice-of-law rule? Suffice it to say that the Principles of the Law of Aggregate Litigation (Principles) adopted in 2010 recognize current realities and draw back from even suggesting selection of a single state's law as a goal. ${ }^{108}$

One might think that in twenty-first century America, with almost a hundred years of experience in product liability cases, state product liability law would be more-or-less uniform. It turns out, however, that Judge Posner's pointed jab in Rhone-Poulenc was raising an issue that matters: ${ }^{109}$ There is considerable variability on important points in the approaches taken to product liability law across the country, much more variability than one might expect. ${ }^{110}$ Hence there is good reason to predict that it makes a big difference whether one applies the product liability law of California or Florida, for example, hence a big difference whether one assesses the fairness of a settlement against one set of standards versus another.

And to bring these questions down to earth, consider this question: Is a court judgment based on law if its critical inputs are bellwether trials in the transferee forum applying the law of a handful of states with respect to claims originating in fifty different states? In the Vioxx cases, the judgment of the court resolved claims by Californians based on estimates of the value of almost 33,000 claims, made by lawyers on the PMC and lawyers for the defendants in the light shed by the outcomes of six trials in Louisiana applying the law of five different states (but not California law). ${ }^{111}$ Can this possibly be what we mean when we say that a court applies the law of the land?

108. Principles of the LaW OF Aggregate Litig. $\S \S 2.05 \mathrm{cmt}$ a a, $3.17 \mathrm{cmt}$. f (AM. LAW INST. 2010) (in class suits, contemplating "no change in the body of choice-of-law principles"; in MDL cases, referring to "existing choice-of-law principles as they currently stand").

109. In re Rhone-Poulenc Rorer Inc., 51 F.3d 1293, 1300 (7th Cir. 1995) (rejecting "single trial before a single jury instructed in accordance with no actual law of any jurisdiction-a jury that will receive a kind of Esperanto instruction, merging the negligence standards of the 50 states and the District of Columbia," and commenting that "one wonders what the Supreme Court thought it was doing in the Erie case when it held that it was unconstitutional for federal courts in diversity cases to apply general common law rather than the common law of the state whose law would apply if the case were being tried" in state court).

110. See Steven P. Zabel \& Jeffrey A. Eyres, Conflict of Law Issues in Multistate Product Liability Class Actions, 19 HAMline L. Rev. 429, 436-44 (1996) (detailed survey describing considerable variability of product liability law).

111. In re Vioxx Prods. Liab. Litig., 869 F. Supp. 2d 719, 721-22 (E.D. La. 2012) (describing settlement in amount of $\$ 4.85$ billion, payable to 32,886 claimants on basis of based on six bellwether trials). 


\section{They Compromise Lawyer Ethics and Violate Client Rights}

Problems arise when lawyers represent multiple claimants whose situations differ - where some claimants should recover more than others from the same defendant, and representing one claimant with full vigor might detract from representation of others. In the MDL context, the matter of ethical responsibilities is complicated further by the fact that lawyers on the PMC may well have obligations not only toward the claimants whom they represent (at one remove), but toward the sidelined lawyers as well. ${ }^{112}$ When settlement becomes the form of a zero sum game in which the size of each recovery affects the size of others, problems of ethical responsibilities are multiplied.

To begin with a simple point, a lawyer is not supposed to represent a client if doing so is "directly adverse to another client" or there is a "significant risk" that representing one client is "materially limited" by responsibilities toward another. ${ }^{113}$ A lawyer may undertake such representation, however, if she "reasonably believes" she can provide "competent and diligent representation" to each client and "each affected client gives informed consent." consent, and it is at least imaginable that a lawyer could provide enough information in the beginning so that the client can give "informed" consent. ${ }^{115}$

More difficult is the matter of obtaining consent to MDL settlements. One might think it a simple task: Each lawyer goes to her clients, explains the settlement to each one by one, and the client can agree or not. But it is not so simple. Each client is entitled to learn the details of the proposed agreement, including the treatment of parallel claims brought by others. The reason to require such broad disclosure is that such settlements are, in the words of the Principles, "interdependent." That is to say, they are part of a package in which the willingness of the

112. Silver, Responsibilities of Lead Lawyers and Judges, supra note 32, at 1987-88, 1990 (authority on ethical responsibilities of lead lawyers in MDL cases is "surprisingly scarce," and may run toward disabled lawyers who are "at risk of being exploited" along with actual claimants).

113. MODEL RULES OF PROF'L CONDUCT r. 1.7(a) (AM. BAR ASS'N 2016).

114. Id. at r. 1.7(b).

115. See Erichson, Beyond the Class Action, supra note 88, at 543, 577-78 (mass collective representation allows for economies of scale to reduce the "per-plaintiff cost of pursuing claims," allowing firms to "invest more heavily in the litigation" by evening the stakes between plaintiffs and defendants).

116. PRinciples of THE LAW OF AgGregate Litig. § 3.16 (AM. LAW InSt. 2010) (nonclass aggregate settlement is "interdependent" if defendant's acceptance is "contingent upon the acceptance by a number of specified percentage of the claimants" or "the value of each claimant's claims [in the settlement] is not based solely on individual case-by-case facts and negotiations"). 
negotiating lawyers to settle any one claim depends on-or is affected by - the resolution of the other claims. For many lawyers in MDL cases, this process is problematic for two reasons:

First, the reward that comes from settlement incentivizes the lawyer representing multiple claimants to recommend and try to sell the settlement to every client, regardless whether it is in her best interest. Now it is true that in ordinary one-on-one lawyer-client relationships the interests of the lawyer and the client do not match exactly. Indeed, we cannot hope to devise a system that solves this problem entirely: It can easily happen that a lawyer's estimate of the amount of recovery after trial exceeds defendant's best settlement offer by a large enough amount to suggest that the client would be better off going to trial, while the lawyer is better off settling at the amount being offered (taking into account the likelihood of success, but putting aside attitudes toward risk). The same thing happens in the MDL settlements, but with two critical differences: One difference is that in the latter context, the stake of the PMC lawyers in selling the deal is exponentially higher because they must invest so much money to bring the case forward to settlement. ${ }^{117}$ The other difference is that lawyers in the MDL setting may shirk their duties to be fully honest with their clients about the range of settlements and degree of recovery because getting consent to settle is so important to them. ${ }^{118}$ These problems lend credibility to the suggestion advanced by one commentator that the world of aggregate settlement is "full of abuse." 119 The problems are exacerbated by the fact that every lawyer who is sidelined by the MDL process, when presented with a proposed deal, does not know and cannot know much about the litigation. She did not play any part in discovery or negotiation, and her sources of

117. Redish \& Karaba, supra note 82, at 144 ("[L]ead counsel may push hard for settlement as opposed to remand, prefer a quick settlement in favor of a protracted discovery period, or advocate for settlement terms that may not be particularly favorable to some or many plaintiffs."); see also Amanda Bronstad, GM Trial Spotlights MDL Flaws, NAT'L L.J. (Feb. 8, 2016), www.nationallawjournal.com/id=1202748997769/GM-Trial-Spotlights-MDL-Flaws (lawyer for one claimant in MDL proceeding files court papers alleging that PMC member may have arranged a "quid pro quo" with defendant to maximize his fees).

118. See In re Guidant Corp. Implantable Defibrillators Prod. Liab. Litig., MDL No. 05-1708, 2009 WL 5195841, at*1 (D. Minn. Dec. 15, 2009) (fining claimant's lawyer $\$ 50,000$ and referring him to disciplinary committee for failing properly to advise clients of range of permissible recovery in MDL settlement); Howard M Erichson, The Trouble with All-or-Nothing Settlements, 58 U. KAN. L. REV. 979, 985-86 (2010) (describing lawyer misconduct in fen-phen litigation in failing to tell settling claimants full amount of settlement, leading to disbarment and prison).

119. Susan P. Koniak, How Like a Winter? The Plight of Absent Class Members Denied Adequate Representation, 79 NOTRE DAME L. REV. 1787, 1797 (2004) (referring to class actions; her argument seems equally applicable to MDL settlements). 
information are lawyers on the PMC who did the work and conducted the negotiations.

Second, a proposed MDL settlement implicitly obligates participating lawyers on the PMC to "sell" the deal to clients and other lawyers for claimants. Indeed, it has happened that such proposals expressly impose a duty on participating lawyers to decline further representation for a client who refuses the deal. Such an obligation puts the lawyer in a conflicted position and is unethical, as a lawyer cannot ethically drop a client merely because he refuses to settle. ${ }^{120}$ It is hardly an improvement on the situation that the implicit understanding among PMC negotiators is that they are to sell the deal to the other lawyers and they in turn are to convince each of their clients in their one-by-one conversations with them.

The matter of client consent is further vexed by a new practice, endorsed by a provision in the Principles, in which lawyers can ask their clients to consent in advance to an MDL settlement proposal if it is approved by a "substantial majority" of claimants. ${ }^{121}$ The difficulty with this proposition is that such consent cannot satisfy even a limp version of the "informed consent" standard because neither the client nor the lawyer, on agreeing to it, can have any actual idea what the settlement will be. A lawyer representing more than one client is not supposed to participate "in making an aggregate settlement" unless each client "gives informed consent" after a consultation that shall include disclosure of "the existence and nature of all the claims . . . and of the participation of each person in the settlement." 122 In taking the position that this protection can be waived in an advance agreement to accept a settlement supported by a "substantial majority" of similar claimants, ${ }^{123}$ the Principles reject significant modern authority finding advance consent invalid. ${ }^{124}$ Indeed, this proposition is an affront to common sense, and strong criticisms separately advanced years ago by Professors Nancy Moore and Howard Erichson are entirely convincing. ${ }^{125}$

120. See Model Rules of Prof'L CONDUCT r. 1.2(a) (AM. BAR Ass'N 2016) (lawyer "shall abide by a client's decision whether to settle a matter").

121. See Principles of the Law of Aggregate Litig. § 3.17, cmt. b (Am. LaW Inst. 2010).

122. MODEL RULES OF PROF'L CONDUCT r. 1.8(g) (AM. BAR ASS'N 2016).

123. PrinCiPles OF THE LAW OF AgGregate Litig. $\S 3.17, \mathrm{cmt}$. b.

124. E.g., Tax Auth., Inc. v. Jackson Hewitt, Inc., 898 A.2d 512, 522 (N.J. 2006) (agreeing that Rule $1.8(\mathrm{~g})$ bars a lawyer "from obtaining consent in advance from multiple clients that each will abide by a majority decision in respect of an aggregate settlement").

125. See Erichson \& Zipursky, Consent Versus Closure, supra note 11, at 292-311; Nancy J. Moore, The Case Against Changing the Aggregate Settlement Rule in Mass Tort Lawsuits, 41 S. TEX. L. REV. 149, 165 (1999) (lawyers cannot agree to settlement "over the objection of any 


\section{JUDICIAL REVIEW AND PARTy ChALLENGE To MDL SETTLEMENTS}

The mechanisms of class suits and MDL converge at a critical point - the point of appraising the fairness of proposed settlements. In MDL and class suits alike, the court conducts an inquiry into fairness and adequacy, and it does so without benefit of the critical voices of most of the claimants. Invariably the court has encouraged negotiations between the PMC and defense counsel; invariably it is they who present the proposed settlement to the court and argue that it is fair. Now the court shoulders the unenviable task of trying to achieve neutrality while taking a cold look at the deal produced under its prodding, and without the benefit of adversary presentation.

\section{A. Initial Review for Fairness and Adequacy}

As noted above, class suits accommodate objectors, ${ }^{126}$ and in MDL cases there is little doubt that outside lawyers for dissatisfied plaintiffsthat is to say, lawyers who are not active in the pretrial preparation because they were not appointed to the PMC or any other committeecan appear and try to get the attention of the court to voice any complaint about the proposed deal. We have no Rule or other black letter law that guarantees such an opportunity, but it is inconceivable that a judge with a legal education would refuse to hear from claimants at this point in the process.

More importantly, however, objectors seldom appear-both in class suits and MDL proceedings. One reason is the low likelihood of success. Another is that claimants in aggregate suits usually don't have effective personal representation (in class suits, they usually don't have their own lawyers; in MDL proceedings most lawyers for claimants have been cut out of the game). In MDL suits, many sidelined lawyers are in states distant from the transferee forum. They have played no role. Their participation has been actively discouraged. In sum, they are ill-prepared to second guess a settlement put together by the PMC and the defense lawyers. Unless these sidelined lawyers invest time digging into the case

\footnotetext{
plaintiff, even when that plaintiff has agreed in advance to be bound by a vote of a majority"). But see Charles Silver \& Lynn A. Baker, Mass Lawsuits and the Aggregate Settlement Rule, 32 WAKE FOREST L. REV. 733 (1997) (arguing that clients should be able to agree in advance to a majorityapproved settlement).

126. FED. R. CIV. P. 23(e). Rule 23(e) requires notice to class members "who would be bound" by the settlement, and a hearing where "any class member" may object, and requires in subsection (b)(3) that damage suits class members, even if already given an opportunity to opt out, must be given another opportunity.
} 
(with no assurance and little prospect of compensation) and then essentially force themselves on the judge and the PMC like uninvited guests at a party, they will have no voice in what happens. These sidelined lawyers know their clients may be bound by the settlement even if they reject it: The expectation is that almost everyone will agree, and the concurrence of a substantial majority may be enough to bind everyone.

\section{B. Wait a Minute: Who Empowered Courts to Review Private Agreements?}

It is actually not clear that courts have authority to review MDL settlements at all: Once again we have no black letter law comparable to Rule 23(e), which authorizes such a function in certified class suits. Indeed, FRCP 41 provides that plaintiff "may dismiss an action without a court order" by filing a stipulation signed by "all parties who have appeared," 127 and arguably courts in such cases have no authority to do anything but dismiss the suit. ${ }^{128}$ Settlements are theoretically matters of private contract, and nothing in the MDL mechanism transforms gathered claims and settlement negotiations into anything else. ${ }^{129}$ In another context, the Supreme Court has held that a federal court that enters judgment dismissing a suit on the basis of private settlement does not retain jurisdiction to enforce the settlement. ${ }^{130}$

We have multiple indications, however, that in practice (whatever the Rules might say and whatever might be "the law") courts have taken it upon themselves to play a role, as happened in the Vioxx litigation and the World Trade Center cases. In the latter, the parties announced a settlement and did not ask the court's opinion or invite its participation, but Judge Hellerstein injected himself into the process, later explaining himself thus:

127. FED. R. CIV. P. 41(a)(1)(A)(i)-(ii).

128. See Anago Franchising, Inc. v. Shaz, LLC, 677 F.3d 1272, 1278 (11th Cir. 2012) (dismissal signed by all parties under FED. R. CIV. P. 41(a)(1)(A)(ii) is "self-executing and dismisses the case" on becoming effective, which occurs "upon filing unless it explicitly conditions its effectiveness on a subsequent occurrence").

129. See Howard M. Erichson, The Role of the Judge in Non-Class Settlements, 90 WASH. U. L. REV. 1015, 1024 (2013) (claimants own their claims; it is claimant's prerogative to dismiss in exchange for compensation; "unauthorized judicial approval may cause just as much mischief as unauthorized judicial rejection"); Grabill, supra note 11, at 165-67 ("unless the parties jointly seek court approval or oversight," courts "have no authority to evaluate, approve, oversee the implementation of, or reject" mass tort settlements).

130. Kokkonen v. Guardian Life. Ins. Co. of Am., 511 U.S. 375, 378-81 (1994) (after dismissing with prejudice, court does not retain ancillary jurisdiction to enforce settlement). 
Neither the Federal Rules of Civil Procedure nor any other rule or law specifically sets out the role of the court in a coordinated mass tort litigation. And there is no authority that explicitly calls for the court to condition approval of a mass settlement on fairness hearings or on compliance with judicially crafted procedural requirements. These things are necessary, however, because the court is the only participant to the proceedings that is truly neutral, and only the court can ensure that conflicts arising in the representation do not unfairly harm plaintiffs, give rise to invidious distinctions among plaintiffs, or unduly advantage defendants. ${ }^{131}$

As noted earlier, the World Trade Center litigation was a "one-off" in that it went forward under a special statute conferring exclusive jurisdiction over "all actions brought for any claim" against air carriers arising out of the September 11 th attacks, ${ }^{132}$ and the claims pending before Judge Hellerstein were gathered under Rule 42, not the MDL statute. ${ }^{133}$ Still, this litigation shows that a court acting in the setting of consolidated litigation can claim authority not found in black letter law to pass on the fairness of settlements.

A third indication that judges in MDL cases have such authority is found in the ALI's Principles of the Law of Aggregate Litigation, which are of course not intended to "restate the law as we have it," but rather to guide courts as they venture into uncharted territory. As Professor Mullenix has pointed out, the choice of language in the title implies that MDL proceedings and class suits are of a piece-variants on a single theme. ${ }^{134}$ Hence it is not surprising that the Principles includes a provision that authorizes judicial approval of MDL settlements, and it is

131. Alvin K. Hellerstein, Democratization of Mass Tort Litigation: Judicial Management to Enhance Claimants' Participation and Control, 41 BRIEF 16, 18 (2012) (footnotes omitted) (original bargain "provided too little for the plaintiffs, and too much for their lawyers," and "contained procedures that lent themselves to arbitrary determinations").

132. See Air Transportation Safety and System Stabilization Act, Pub. L. No. 107-42, § 408(b)(3), 115 Stat. 230, 241 (2001) (signed into law eleven days after the September 11, 2001 terrorist attacks, creating the Victim Compensation Fund and channeling litigation into federal court in New York); see generally FEINBERG, WHAT Is LIFE WORTH?, supra note 35, at 169-72 (describing process run by the author on pro bono basis that distributed more than $\$ 7$ billion to claimants).

133. See Mariani v. United Air Lines, Inc., No. 01 Civ. 11628, 2002 WL 1685382, at*1 (S.D.N.Y. July 24, 2002) (ordering consolidation of all suits arising out of World Trade Center disaster consolidated under FED. R. CIV. P. 42); FED. R. CIV. P. 42(a) (providing that actions pending before a federal district court may be joined or consolidated if they "involve a common question of law or fact").

134. See Mullenix, Aggregate Litigation, supra note 94, at 541 (noting that "nonclass aggregate contractual settlement" is a term that "deliberately resonates in the familiar language of the class action while simultaneously rejecting the class concept," now institutionalized in the ALI's Principles). 
also not surprising (for a very different reason) that the Principles view the role of the court as limited. ${ }^{135}$ In any event, the Principles include a provision (the very last one) titled "Limited Judicial Review for NonClass Aggregate Settlements." 136 This provision says that any claimant who agrees to be bound by a settlement favored by a substantial majority may "challenge" it on grounds of technical irregularities or because it is not "procedurally and substantively fair and reasonable," and provides further that such challenge may be brought in MDL cases in the transferee forum or "in any court of competent jurisdiction."137 The Principles also include a provision stating that "enforceability" of an MDL settlement depends on whether it is "fair and reasonable" from both a "procedural standpoint" and a substantive standpoint. ${ }^{138}$

The comment going with this provision says procedural fairness is more likely when claimants "share some prior relationship that accustoms them to working together," adding that "common membership in a trade association or union" makes procedural fairness of a negotiated deal more likely, and it cites "asbestos claimants with no prior relationship to one another and relatively different claims" as a situation where more care is required. ${ }^{139}$ "Substantive" fairness may turn, in the words of the Principles, on consideration of "the costs, risks, probability of success, and delays in achieving a verdict" and on whether claimants are "treated equitably (relative to each other) based on their facts and circumstances" and on whether "particular claimants are disadvantaged by the settlement considered as a whole."140 Not surprisingly, these substantive criteria resemble those developed by courts applying FRCP 23(e) in appraising class action settlements. ${ }^{141}$ The provision goes on to say that such claimants may also challenge "the amount of his or her share" on grounds of fairness. ${ }^{142}$

Given these indicators, it seems likely that the practice of judges passing on MDL settlements will become universally recognized and-at

\footnotetext{
135. See Principles of the LaW Of Aggregate Litig. § 3.18 (Am. LaW InSt. 2010).

136. Id.

137. Id. at $\S 3.18(\mathrm{a})$.

138. Id. at $\S 3.17(\mathrm{~d})-(\mathrm{e})$, cmt. e.

139. Id. at $\S 3.17 \mathrm{cmt}$. $\mathrm{d}(5)$.

140. Id. at $\S 3.17(\mathrm{e})$, cmt. e.

141. The Civil Rules Advisory Committee is studying the question whether to amend FED. R. Civ. P. 23 to include criteria for judging the adequacy of settlements. See Advisory COMM. ON Civil Rules, Rule 23 Subcommittee Report, in AgENDA Book: AdVISORY COMMITTEe ON CiviL RULES 247-48 (Apr. 2015), http://www.uscourts.gov/sites/default/files/fr_import/CV2015-04.pdf.

142. PrinCiPLES OF THE LAW OF AGgregate Litig. § 3.18(b).
} 
least in that sense-achieve legitimacy. ${ }^{143}$ Even though litigants in MDL cases could simply agree to settlement and a judgment of dismissal, they are more likely to prefer an order of the court that contains and endorses the terms of the agreement. Arguably this approach necessarily means that the court is involved in settlement: Adding a court order is not a mere formality. For one thing, it enables the parties to invoke the protections of claim preclusion, over which they have considerable control because the terms of the agreement can specify the nature and extent of claim preclusion. ${ }^{144}$ For another thing, entry of judgment may enable claimants to enforce the settlement by execution (and may confine the extent of execution), although such judgments are also treated as judicially-approved contracts, and it is not always the case that they can be enforced by writ as opposed to further proceedings seeking judicial enforcement. ${ }^{145}$ In sum, the judgment and accompanying order mean that the settlement is no longer merely a contract, but an official act that puts the authority of the court behind the agreement and sometimes extends the authority of the court over the agreement. ${ }^{146}$

It seems worth considering the possibility that a claimant who does not agree to a settlement can object and, if overruled, continue to challenge it. Of course the expectation is nay-saying claimants will say

143. See, e.g., Sullivan v. DB Invs., Inc., 667 F.3d 273, 334, 334 n.3 (3d Cir. 2011) (Scirica, J., concurring) ("there is no prescribed independent review of the structural and substantive fairness of a settlement" outside of class actions, but "some MDL transferee judges have treated the MDL proceedings as quasi class actions and restricted contingent fee agreements in non-class aggregate settlements under their equitable and supervisory powers"); In re Methyl Tertiary Butyl Ether (“MTBE”) Prods. Liab. Litig., 578 F. Supp. 2d 519, 525-28 (S.D.N.Y. 2008) (reviewing settlement in MDL for good faith to protect settling defendants against contribution claims by nonsettling defendants).

144. 18A Charles Alan Wright, Arthur R. Miller \& Edward H. CoOper, Federal PRACTICE AND PROCEDURE $\S 4443$ (2d ed. 2002) (“consent judgments ordinarily support claim preclusion but not issue preclusion," and claim preclusion "may extend to claims that were not even formally presented," but issue preclusion is often denied on the basis of "intent of the parties and the lack of any actual adjudication").

145. See Andrews v. Roadway Express Inc., 473 F.3d 565, 568, 568 n.2 (5th Cir. 2006) (consent decree approved by judicial order is a "judgment" for purposes of FED. R. CIV. P. 69); United States v. Kellum, 523 F.2d 1284, 1287 (5th Cir. 1975) ("consent decree is [i]n many respects ... a contract between the parties," but it also has "the same force and effect as any other judgment until set aside in the manner provided by law"). See also Note, The Consent Judgment as an Instrument of Compromise and Settlement, 72 HARV. L. REV. 1314, 1316-17 (1959) (consent judgments are "ordinarily enforcible [sic] in the same manner as other judgments," and treating them as mere contracts would "remove one incentive" to settle and require "consumption of additional judicial resources," but a court should not be compelled by consent of the parties "to grant a type of relief which it would not have granted had the action been contested," and courts can modify consent decrees).

146. See Bell v. Schexnayder, 36 F.3d 447, 449-50, 449 n.2 (5th Cir. 1994) (where court's order of dismissal "expressly provided that the parties could, within 60 days, move to reopen the case to enforce the settlement," court retained jurisdiction). 
nothing after rejecting the proposal: They are expected to pursue their own remedies in the pending litigation, although they must first persuade the transferee forum to return their cases to the courts of original filing, or to other courts where venue would be proper for unsettled claims. In the Vioxx case, dissenting claimants sought to challenge the settlement but the judge disallowed the challenge and the Fifth Circuit rejected their appeal. ${ }^{147}$ The Principles appear to agree with this view, as they provide only for challenges to a settlement by persons otherwise bound by it. ${ }^{148}$ Left out are plaintiffs who reject the settlement. The notion is that if one is not bound, why should he complain about those who agree to what was proposed? Arguably, however, even claimants who reject a settlement as unfair should be able to continue to challenge it. Such a claimant is not a disinterested bystander, and she too expects fair treatment from the PMB and from any settlement. She should have not only the option of accepting a settlement or pursuing her own remedy, but also the option of objecting that a deal reached with the leverage provided by her claim, by lawyers purporting to represent her interests, is unfair or inadequate. ${ }^{149}$

\section{Later (Collateral) Challenge}

The question whether an MDL settlement is open to later challenge may seem unworthy of consideration: Of course settlements may be set aside if they are not performed, and on other grounds that apply generally to relief from contractual obligations. But one attraction of MDL settlements is that they are arrangements that enjoy both judicial imprimatur and contractual commitment, and the latter element in their nature supposedly immunizes them from attack that might succeed in cases in which such arrangements enjoy only the former-on grounds relating to inadequacy, unfairness, or failures by lawyers adequately to represent claimants.

147. See In re Vioxx Prods. Liab. Litig., 388 F. App’x 391, 395 (5th Cir. 2010) (citing TransAm. Ref. Corp. v. Dravo Corp., 952 F.2d 898, 900 (5th Cir. 1992)) ("non-settling parties generally have no standing to challenge the settlement").

148. See Principles of the LaW OF AgGregate Litig. § 3.18(a) (Am. LAW Inst. 2010) (any claimant "who is subject to a settlement" can bring a challenge).

149. See Doe v. Lexington-Fayette Urban Cty. Gov’t., 407 F.3d 755, 760-64 (6th Cir. 2005) (allowing collateral attack on judgment dismissing putative class suit; court erred there in entering judgment of dismissal, based on settlement of named plaintiffs' claims, by failing to provide notice to members of putative class; earlier judgment was void). 


\section{Effect of the Impact of Common Law (Contract; Agency; Professional Responsibility)}

The consent of claimants (and of course defendants) to a settlement helps produce a durable closure, and contract principles help achieve this result. For example, a contracting party cannot avoid her obligations on ground of mistake if the contract allocates to her the risk of mistake or if circumstances make it reasonable to allocate that risk to her. ${ }^{150}$ Specifically in the area of settlement agreements, efforts to set them aside typically fail, and courts stress the importance of such agreements and emphasize that public policy favors them. ${ }^{151}$

Yet contract law is not an insuperable barrier: One party's mistake on a "basic assumption" underlying an agreement makes it voidable if enforcement would be "unconscionable."152 Settlement contracts may also be set aside for fraud, which can include erroneous advice to the settling party about elements of recovery that a claimant is losing in agreeing to settle. ${ }^{153}$ And the law of professional responsibility affects the enforceability of settlements. If the client's informed consent was not obtained, or if she purported to waive her right to informed consent by agreeing in advance to be bound by a substantial majority vote and the waiver is invalid (as indicated by current law), the settlement can be set aside. Dissatisfied claimants in MDL cases have in fact mounted such arguments, generally without success. ${ }^{154}$

150. RESTATEMENT (SECOND) OF CONTRACTS $§ 154$ (AM. LAW INST. 1981) (contracting party bears risk of mistake if it is "allocated to him" or he knows he has "limited knowledge" of the facts but "treats his limited knowledge as sufficient" or risk is "allocated to him by the court" as reasonable).

151. See, e.g., Mardanlou v. Gen. Motors Corp., 69 F. App’x 950, 951-52 (10th Cir. 2003) (refusing to set aside judgment on settlement of personal injury claim against auto maker and rejecting claim that plaintiff was pressured to settle and was "easily manipulated and persuaded" because he was on medication during negotiations).

152. RESTATEMENT (SECOND) OF CONTRACTS $\S 153$ (where a party's mistake on "a basic assumption" underlying her agreement has a "material" and "adverse" effect on the agreed exchange, the agreement is voidable if she "does not bear the risk of the mistake" and enforcement would be "unconscionable" or "the other party had reason to know of the mistake" or in fact "caused the mistake").

153. See Seybert v. Cominco Alaska Expl., 182 P.3d 1079, 1094-95 (Alaska 2008) (worker who settled compensation claim with employer could set it aside on ground of "constructive fraud, duress, or misrepresentation," including material misrepresentation relating to claimant's eligibility for permanent total disability benefits); Coaker v. Wash. Cty. Bd. of Educ., 646 So. 2d 38, 38-41 (Ala. Civ. App. 1993) (even innocent representations of material fact on which plaintiff relies can show fraud that would justify setting aside settlement; here plaintiff did not get the "light duty" he was promised, which showed fraud and permits court to set aside settlement).

154. See, e.g., In re Vioxx Prods. Liab. Litig., 388 F. App'x 391, 396-97 (5th Cir. 2010) (citing public policy favoring settlements). 
The enforceability of an MDL settlement is also affected by agency law, quite apart from principles of contract and professional responsibility. The lawyer as agent for his client has a duty to inform her of facts that the lawyer "knows or has reason to know that the principal would wish to have" or that are "material to the agent's duties to the principal." 155 And the lawyer owes a duty of loyalty to her client, which entails not working for the lawyer's own benefit outside the terms of the agency and not working for other principals with whom the agent is dealing. ${ }^{156}$

\section{Effect of Preclusion Law (Hansberry, Principles of Aggregate Litigation)}

There is no doubt that claim preclusion law operates in connection with an MDL judgment based on a settlement agreement, at least to the extent that the parties so provide. In other words, assuming that a consent judgment is procedurally valid (rendering court has jurisdiction; judgment comports with due process) and the underlying agreement so provides, the judgment resolves claims that were brought and that might have been brought.

The harder question is whether MDL judgments on aggregate settlements are subject to collateral challenge raising issues of due process unrelated to jurisdiction - due process issues turning on adequate representation and the fairness and adequacy of the settlement. Here we enter a nether region, and it is arguable that preclusion law has nothing to say. We are talking now about issue preclusion, which applies to issues "actually litigated" (and necessary to a final judgment). ${ }^{157}$ Although adequate representation is "actually litigated" in class suits at the certification stage, it is not litigated - at least formally-in MDL litigation leading to settlement. Indeed, avoiding this question is part of the charm of MDL litigation. ${ }^{158}$ In short, it is at least possible, as one

155. Restatement (THIRd) OF AGENCY $§ 8.11$ (1) (AM. LAw InST. 2006).

156. See Model Rules of Prof'L CONDUCT r. 1.7(a)(2) (AM. BAR Ass'N 2016) (lawyer shall not represent client if representation "will be materially limited by . . . a personal interest of the lawyer").

157. Restatement (SECOND) OF JudGMENTS $§ 27$ (AM. LAW INST. 1982) (issue preclusion applies to "an issue of fact or law" that was "actually litigated and determined by a valid and final judgment" and is "essential to the judgment").

158. The other branch of preclusion law (claim preclusion, or res judicata) comes into play. One of the attractions of aggregate litigation for defendants is closure, and a valid MDL judgment on a settlement forecloses further litigation of claims actually brought and those that might have been brought. 
observer has lamented, that MDL settlements represent "a triumph of contract over constitution," and that due process is simply irrelevant. ${ }^{159}$

But this conclusion is hard to accept. After all, there is a court judgment, and the judgment (not just the underlying agreement) is instrumental in concluding claims (a kind of property right), and perhaps in enforcing them by execution or by the sheer force of official endorsement. So it cannot really be that issues of adequate representation and other aspects of due process are irrelevant.

Perhaps equally important, it seems that the transferee court in MDL cases decides, at least implicitly, issues of adequate representation on account of due process concerns. Although the court acts without guidance of rule or statute, and without any formal mechanism allowing review, the court does appoint the PMC, and does supervise fee arrangements for the PMC and the sidelined lawyers, and does pass on the fairness and adequacy of settlement, rejecting settlements that are not fair and adequate. The matter of adequate representation has to be a factor in all these matters.

If due process is indeed relevant, there must be a way of raising the point in a later suit, although the Principles assume otherwise. The MDL gathering mechanism leaves the various suits pending in the courts of original filing while depriving those courts of "jurisdiction" to take any further action. ${ }^{160}$ Building on this reality, the Principles allow for challenge to an MDL settlement only in the court where the action is pending after transfer (the transferee forum), ${ }^{161}$ and they do not refer to due process or adequate representation as such. They envision challenges leading to inquiry in four areas-whether consent to the settlement was properly obtained, whether clients received adequate advice on options, whether the full terms of the settlement were disclosed, and whether the settlement was "substantively fair and reasonable."162 Of course all these issues are significant, and they relate to the questions of due process and adequate representation. But missing

159. See Linda S. Mullenix, Reflections of a Recovering Aggregationist, 15 NEV. L.J. 1455, 1471 (2015).

160. Transfers under 28 U.S.C. $\S 1407$ (2012) don't result in dismissing the original suits (they are still "pending" in transferor fora), but full authority goes to the transferee forum. See Glasstech, Inc. v. AB Kyro OY, 769 F.2d 1574, 1577-78 (Fed. Cir. 1985) (on transfer, transferor forum is "divested of jurisdiction").

161. Principles of the LaW of Aggregate Litig. § 3.18(a) (AM. LaW Inst. 2010) (in a nonclass aggregate settlement, claimant is entitled to mount a challenge, but the challenge is to be brought where claimant's case "is or was pending or, if no case is or was pending, in any court of competent jurisdiction").

162. Id. at $\S \S 3.17-3.18$. 
from the Principles is any broader recognition of such issues, of the sort that can be raised in class actions, or any willingness to allow collateral challenge in a new lawsuit.

It should be instructive to consider the law governing collateral challenge to judgments in class suits based on claims of inadequate representation. Most informative are three critical cases and the position taken by the Principles, although the cases and the academy are deeply divided on this subject.

The first case is Hansberry, which holds that a judgment in a class action can be challenged in a later suit brought by claimants whose rights were purportedly adjudicated in the earlier suit as members of the class. ${ }^{163}$ There are many reasons why Hansberry came out as it did, not least being reluctance to enforce a racial covenant, the fact that the new plaintiffs could not have been identified in the earlier suit or in any way included in it, the fact that they didn't fit the purported class (they would resist the covenant; the class sought to enforce it), and the fact that the defendant in the earlier suit (whose interests did line up with those of the new plaintiff) did not purport to represent a class. ${ }^{164}$ Hansberry requires the new court to take what we can call a "second look" at what the first court did, to decide whether the new plaintiff's interests were adequately represented before, and Hansberry holds that the matter of adequate representation is key to insuring due process. ${ }^{165}$

Second is the Epstein case, which stands for the proposition that collateral challenge to a class judgment for inadequate representation is not proper. ${ }^{166}$ Here too, other forces are in play. The case brought issues of full faith and credit because the suit leading to judgment on a settlement was a derivative action in state court in Delaware, and the other suit was a class action in federal court in California raising exclusively federal claims (Hansberry did not raise issues of full faith and credit, or the effect of a state court settlement on exclusively federal claims). ${ }^{167}$ Not surprisingly, given its decision in Marrese that state preclusion law governs the effect of state judgments, even on claims that

163. Hansberry v. Lee, 311 U.S. 32, 43-44 (1940). Eight years later the Court confronted the question it avoided by disposing of Hansberry on procedural grounds. See generally Jay Tidmarsh, The Story of Hansberry: The Rise of the Modern Class Action, in Civil PROCEDURE STORIES 233 (Kevin M. Clermont ed., 2d ed. 2008); Shelley v. Kraemer, 334 U.S. 1, 19-23 (1948) (holding that racial covenants are unenforceable).

164. See generally Hansberry, 311 U.S. at 37-46.

165. See id. at 43-44.

166. See Epstein v. MCA, Inc. (Epstein III), 179 F.3d 641, 648-50 (9th Cir. 1999).

167. Matsushita Elec. Indus. Co. v. Epstein (Epstein I), 516 U.S. 367, 369-73 (1996). 
can only be brought in federal court, ${ }^{168}$ the Court held in Epstein I that the federal court in the second suit was to apply Delaware preclusion law, but it declined to say whether adequate representation could be raised in the California suit. ${ }^{169}$ On remand, the Ninth Circuit held in Epstein II that adequacy of representation in the Delaware suit could be reviewed, ${ }^{170}$ but on rehearing after a change in personnel (and one judge's change of mind), the Ninth Circuit in Epstein III concluded that collateral review was barred after all, because the matter of adequate representation had been adjudicated in the original suit. ${ }^{171}$

Third is the Stephenson case, which (like Hansberry) stands for the proposition that a judgment in a class action is open to challenge later by a claimant whose rights were purportedly adjudicated because he was a member of the class. ${ }^{172}$ Again, many forces are in play. First, the new plaintiff (like the new plaintiff in Hansberry) could not have been identified during the earlier suit (he was asymptomatic), and the reviewing court in the new suit said no court had addressed the question of adequate representation for him or people like him. ${ }^{173}$ Second, Stephenson came after Amchem and Ortiz had condemned use of class judgments to resolve future claims, which is what the Agent Orange judgment challenged in Stephenson purported to do. ${ }^{174}$ Finally, some of the ironies that mark the Agent Orange case reappeared in Stephenson: Judge Winter's opinion for the Second Circuit affirmed Judge Weinstein's judgment in Agent Orange while taking the view that class certification is inappropriate in mass exposure cases - in effect saying "we'll uphold what you did, but this is not usually the kind of case that merits class treatment." before Judge Weinstein, who dismissed them on the merits as barred by

168. Marrese v. Am. Acad. of Orthopaedic Surgeons, 470 U.S. 373, 381-87 (1985).

169. Epstein I, 516 U.S. at 379 n.5 (declining to address due process claim of inadequate representation "because it is outside the scope of the question presented in this Court"). See also id. at 395-99 (Ginsburg, J., concurring) (Justice Ginsburg also declines to resolve this issue).

170. Epstein v. MCA, Inc. (Epstein II), 126 F.3d 1235, 1243-51 (9th Cir. 1997) (reviewing Delaware judgment and concluding that plaintiffs in the California suit were not adequately represented), withdrawn, 179 F.3d 641 (9th Cir. 1999).

171. Epstein III, 179 F.3d at 648-50 (concluding that collateral review is foreclosed).

172. Stephenson v. Dow Chem. Co., 273 F.3d 249, 257-59 (2d Cir. 2001) (citing Hansberry for principle that propriety of collateral challenge to class judgments is "amply supported," and stating that these rest on "due process concerns"), aff" $d$ in part and vacated in part, 539 U.S. 111 (2003).

173. See id. (no court has yet addressed "the adequacy of representation for those members of the class whose injuries manifested after depletion of the settlements [sic] funds").

174. See id. at 257-61.

175. See In re "Agent Orange" Prod. Liab. Litig. MDL No. 381, 818 F.2d 145, 165-67 (2d Cir. 1987) (expressing skepticism toward class treatment of mass tort cases, but affirming class treatment here because government contractor defense raised critical common question). 
the military contractor defense - in effect saying that "the original claimants were entitled to victory because they cooperated and settled," and "you are entitled to a collateral attack because the reviewing court said so," but "you can't recover because really nobody is entitled to recover on account of the military contractor defense."

Into this disarray stepped the Principles of the Law of Aggregate Litigation in 2010. As noted above, they include a provision that is close to Epstein III in barring most collateral challenges to judgments in class actions, on the theory that the matter of adequate representation was actually adjudicated in the original suit, so errors on this point should be addressed on direct appeal. The Principles do allow collateral challenges claiming that the original court lacked personal or subject matter jurisdiction, or failed "to make the necessary findings of adequate representation" or to afford "reasonable notice and an opportunity to be heard as required by applicable law." "177 Otherwise, however, collateral challenges are blocked. Importantly, the Principles limit even direct challenges raising issues of adequate representation, contemplating corrective measures only for "structural conflicts of interest," meaning those "in existence at the time of the aggregation decision" or that "emerge in the course of the aggregate litigation." 178

\section{Policy Arguments Favoring Collateral Challenge}

As a beginning point, we should remember that the rendering court does not decide what effect should be given to a judgment in a later suit, a proposition that applies as much to class suits as to others. In the ordinary case, of course, she simply determines which parties are bound by the earlier judgment, what issues were necessarily resolved and what claims were covered, and those considerations determine the preclusive effect of the earlier judgment. ${ }^{179}$ There is no "second look" in the sense

176. In re "Agent Orange" Prod. Liab. Litig., 373 F. Supp. 2d 7, 44-45 (E.D.N.Y. 2005) (manufacturers were entitled to government contractor defense; claims dismissed), aff'd sub nom. Vietnam Ass'n for Victims of Agent Orange v. Dow Chem. Co., 517 F.3d 104, 124 (2d Cir. 2008) (affirming dismissal on ground of government contractor defense).

177. Principles of the LAW OF AgGregate Litig. § 3.14(a)(2) (AM. LaW Inst. 2010). Under the Principles, "direct appeal" is "the normal vehicle" for challenging a judgment based on a class settlement. See id. at §3.14(a) (also exempting what might be called direct challenges in form of motions for relief from judgment under FED. R. CIV. P. 60(b) or similar provisions).

178. See id. at $\S 2.07(\mathrm{a})(1)$, cmt. d.

179. In ordinary circumstances-imagine one plaintiff suing one defendant, and later suing the same defendant on the same claim again. Here the second judge must resolve the technical points: Are they really the same parties? Is it really the same claim or same transaction? Once those questions are answered, the prior judgment either controls the later case or it has no impact at all. 
of examining adequacy of representation. For four good reasons, however, aggregate litigation - both class suits and MDL judgments on settlements - is and should be different.

First, the risk of unjust results for claimants is magnified when multiple claims are resolved en masse. Even assuming that lawyers are thorough, a settlement is likely to overcompensate some and undercompensate others. It is true that problems with asymptomatic claimants, of the sort that appeared in class litigation in Ortiz and Amchem, are less likely in MDL cases: Each MDL claimant has a lawyer and filed suit, which usually means he knows about and suffers current injuries. Still, the difficulties that come with suits for ongoing ailments or injuries, which include variation in the nature and severity of harms, estimating the future course of events, and trying to compensate for ongoing treatment or suffering or losses, are magnified in all aggregate litigation (class suits and MDL cases alike). Combining claims leads to categorizing and constructing grids in an effort to achieve similar treatment for similarly-situated claimants. Indeed, the effort may even lead, in the interest of compromise, to a settlement that pays each claimant the same amount, which at least avoids the corrosive effects of administrative costs on total recovery. It is these realities that stand behind the provision in the Principles that let claimants, even after having agreed to a settlement, challenge it in the rendering court as "substantively" unfair. ${ }^{180}$

Second is the powerful reason that this article examines. Because no real testing attends MDL settlements, the best chance for a critical look comes when a claimant allegedly bound by it hires a lawyer and brings another suit. We have seen why-the active players in MDL settlements are the lawyers who negotiate the deal and the judge who presides over it, and they all want to get the settlement approved. The cautious attitude toward binding nonparties to a judgment, as evinced in Hansberry and reiterated in more recent decisions, is best understood as paving the way for collateral review because of an abiding suspicion that aggregate treatment of claims ventures so far from our ideal of personalized justice that the outcome demands a departure from our approach to conventional litigation, in which aggregate judgments can be tested for fairness not

180. PRINCIPLeS OF THE LAW OF AGgRegate Litig. § 3.18(a). Illustration 3 indicates that a claimant who signed a valid waiver of the right to reject a settlement approved by most other claimants may mount "a timely challenge" if each claimant is to receive "the same amount of money" even though some "suffered serious permanent injuries, while others suffered only minor or temporary injuries." $I d$. at $\S 3.18$ illus. 3. This example illustrates a challenge raising issues of "substantive fairness." 
only by the original judge, but by a later judge when a new claimant argues that the original judgment does not resolve her rights. ${ }^{181}$

Third, the transferee forum has no specific criteria to apply in gauging the propriety of moving beyond discovery into trial or settlement because these outcomes are foreclosed by the terms of the MDL statute. Class suits under Rule 23 must satisfy common question, typicality predominance, manageability, and superiority requirements, and provision is made for subclasses, for treatment of selected issues on a classwide basis, and for intervention by class members. And the trial court has an ongoing duty to insure that counsel acts in the best interests of the class. In contrast, cases gathered under the Multi-District Litigation statue need only satisfy a "common question" standard, with almost everything left to the unguided discretion of the trial judge.

Fourth, the consent of the clients of sidelined lawyers is not likely to reflect a genuine choice. Lawyers are sometimes expressly obliged to try to sell the deal, but they're inclined in that direction even not formally obligated, to the point that they are sorely tempted to give short shrift to their ethical duties. Most claimants consent; objectors are rare; sidelined lawyers are seldom in a position to complain in the interests of their clients, even if they were so inclined. In short, both client consent and the objectivity of advice given by lawyers for claimants are seriously compromised. Lingering uneasiness over this matter of client choice underlies the provision in the Principles allowing limited challenge by those who sign on. ${ }^{182}$

In MDL settlement cases, there are two final concerns. One is that a judgment on an MDL settlement raises jurisdictional concerns. Forcing unhappy claimants to go to the transferee forum to challenge such a settlement poses a significant hardship and operates as a major hurdle. It is true that the Court in the Shutts case approved the exercise of personal jurisdiction over absent claimants in a class suit, even though they lacked

181. See, e.g., Taylor v. Sturgell, 553 U.S. 880, 901 (2008) (rejecting extension of preclusion based on "virtual representation" based on "identity of interests" in part because it would be "shorn of the procedural protections prescribed in Hansberry"); Ortiz v. Fibreboard Corp., 527 U.S. 815, 846 (1999) (quoting Hansberry v. Lee, 311 U.S. 32, 40 (1940)) (rejecting asbestos mass settlement for failing to satisfy FED. R. CIV. P. 23 and citing Hansberry as resting on a "principle of general application" entitling everyone to a day in court); Phillips Petroleum Co. v. Shutts, 472 U.S. 797, 805 (1985) (adjudicating court "may not be able to predetermine the res judicata effect of its own judgment").

182. See Principles of the LaW OF AgGregate Litig. § 3.18. Illustration 2 says a claimant who signed an invalid waiver of right to informed consent-failing to warn that claimants "will be bound by any proposed settlement that a substantial majority of claimants approves"-may challenge for "procedural" unfairness. See id. at $§ 3.18,318$ illus. 2. 
connection to the forum. ${ }^{183}$ The theory was that they had no obligation to approach or participate in proceedings, and class counsel represents all members. ${ }^{184}$ This loose attitude is less appropriate in MDL cases in which claimants have their own lawyers and have suits on file elsewhere, and in which the transferee forum admittedly cannot try the cases. The Principles, which severely restrict collateral review in any event, also purport to limit to the transferee forum any challenge adequacy of representation, in effect obligating them to do what Shutts assumed that they would not have to do. ${ }^{185}$

Lastly, the transferee forum in an MDL case lacks authority to try the cases that it is managing. When PMC and defense counsel agree to a settlement, the atmosphere is one in which there is no threat of trial. Absent at least the possibility of a trial, there is no assurance that the settlement reflects "what the case is really worth." In Amchem, which condemned the purported global settlement of asbestos claims, one of the main concerns of the Court was that a case certified solely for purposes of settlement leaves counsel for the class "disarmed."186 For different reasons, a similar difficulty bedevils MDL settlements.

\section{Policy Arguments Against Collateral Challenge}

The argument against collateral challenge is easily stated, and it rests on two overarching points. First, judgments in MDL settlement cases serve a valuable purpose in our modern era, so they must be enabled, which in turn means that they must be final and resistant to collateral challenge. ${ }^{187}$ The hope is to encourage and legitimize this procedure, to make it into a more powerful engine for resolving disputes, which entails the capability of delivering on the promise of enforceable global resolutions of disputes, getting money to claimants and getting

183. Shutts, 472 U.S. at 811-12.

184. Id. at $808-10$ (stating claimants in class suits are in "different posture" from defendants and "are not subject to other burdens," having no obligation to "hire counsel or appear" and ruling that the absent claimant "is not required to do anything").

185. See Principles of THE LAW OF AgGregate Litig. § 3.18(b) (stating a claimant who "contests the amount" of settlement may bring challenge in court where case "is or was pending").

186. Amchem Prods., Inc. v. Windsor, 521 U.S. 591, 621 (1997). See generally Howard M. Erichson, The Problem of Settlement Class Actions, 82 GEO. WASH. L. REv. 951, 987-88 (2014) (concluding Amchem was actually "not cautious enough" in its approach to class action settlements by allowing the possibility of settlement classes "without plenary class certification," thus enabling negotiation "with deleveraged would-be class counsel") (emphasis added).

187. See Principles of the LAW OF AGgregate Litig. $§ 3.14 \mathrm{cmt}$. a (allowing collateral challenge to class judgments based on settlements, where these were or could have been raised during the litigation, undermines "integrity of the settlement process"). 
defendants off the hook while saving judicial resources. These laudable aims are essentially an appeal to necessity and a surrender to the pressures of mass wrongs and limited resources. Second, the Principles rest on the view that there is no modern need for collateral challenge. In the setting of class suits, modern procedure under Rule 23 ensures adequate consideration of matters like adequate representation in the initial suit. At the time of Hansberry, class procedure was far less developed, and one could not depend on the court in a class action to exercise the kind of supervision, and entertain the kinds of challenges, that might in the end assure adequate representation of the interests of class members. ${ }^{188}$ In the setting of MDL settlements, all that is necessary is general supervision by the judge and a limited chance for claimants to be heard in the original proceedings.

\section{Scope of Collateral Review (What Should It Look Like?)}

In the most promising view of it, the central question to be addressed in a collateral challenge is whether the MDL settlement adequately compensated the claimant now pressing forward. The next question is harder: Should "adequately compensated" be understood as referring to the situation of one who voluntarily accepts group representation, or should it be understood as referring to the situation of a claimant individually represented by her lawyer?

In the setting of class suits brought under Rule 23(b)(3), it is at least plausible to say that claimants who don't opt out have chosen to be part of the group and must accept the consequence of group representation, in which the lawyer represents the class and not each individual. ${ }^{189}$ This perspective then justifies approaching the question of adequate settlement by examining not the prospect for individual recovery by class members if they brought their own suit, but rather the prospect of success for the group as a whole.

In appraising settlements in class suits then, courts have considered

188. See Tidmarsh, supra note 163, at 265 (Illinois law required "no further action beyond pleading a claim as a class action," and there was no certification procedure; whether it was a class action was not decided until someone later argued that an opponent was bound as member of an earlier class).

189. It is plausible also to reach the utterly different conclusion that even suits brought under Rule 23(b)(3) improperly distort individual claims to the point that they are unrecognizable as such. See Martin H. Redish, Class Actions and the Democratic Difficulty: Rethinking the Intersection of Private Litigation and Public Goals, 2003 U. CHI. LEGAL F. 71, 77 (2003) ("[W] hat purports to be a class action, brought primarily to enforce private individuals' substantive rights to compensatory relief, in reality amounts to little more than private attorneys acting as bounty hunters, protecting the public interest by enforcing the public policies embodied in controlling statutes.”). 
the complexity, expense and likely duration of going to trial, the reactions of claimants to the proposed deal, the risks to claimants of losing on the issues of liability or damages if the case is tried, the stage of proceedings at which the proposed settlement has been put together, the ability of defendants to pay, and the size of the settlement in relation to estimates of likelihood and size of possible recovery (sometimes called the Grinnell or Girsh factors in recognition of prominent decisions that produced such lists). ${ }^{190}$ Courts have also examined the performance and resources of class counsel, the manner and extent of discovery, and the conduct of the negotiations, evaluating settlements for "substantive fairness," and examining the "negotiating process."191 What counts, then, is "justice for the class" rather than "justice for each claimant." Even the strikingly original approach suggested by Professor David Dana, which approaches adequacy of class settlements by asking a "Rawlsian" question (What would a class member accept "before knowing her position in the class[?]"), accepts the proposition that a reasonable class settlement does not have to track what would be reasonable if the claimant were suing alone. ${ }^{192}$

In the setting of individual suits gathered in the MDL process, the question should be different. There is nothing in the gathering process that claimants agree to- their individual suits get transferred without their consent; they don't consent to representation by the PMC (tacitly, by not "opting out"); the lawyers they chose to represent are sidelined from what is now the aggregate suit. It is true that they can agree or not agree to the proposed settlement, and it is true that something similar can happen in class suits. In both situations, the first opportunity of a claimant to participate or decline may come when lawyers have put together an agreement and invite participation or not (in class suits, joining the class and settling the case collapse into a single choice). But claimants in gathered MDL suits made and acted on a different choicehiring a lawyer and coming forward individually with their claims. And they may already have been pressed to accede to any settlement approved by a supermajority (a choice necessarily made in complete ignorance, as described above). The pressures and informational deficits

190. Girsh v. Jepson, 521 F.2d 153, 156-57 (3d Cir. 1975) (quoting City of Detroit v. Grinnell Corp., 495 F.2d 448, 463 (2d Cir. 1974), abrogated by Goldberger v. Integrated Res., Inc., 209 F.3d 43 (2d Cir. 2000)); Grinnell, 495 F.2d at 463. See also In re Prudential Ins. Co. Sales Practices Litig. Agent Actions, 148 F.3d 283, 322-29 (3d Cir. 1998) (extending consideration and approval of settlement of $\$ 1-\$ 2$ billion in nationwide class suit).

191. E.g., Charron v. Wiener, 731 F.3d 241, 247-51 (2d Cir. 2013).

192. David A. Dana, Adequacy of Representation After Stephenson: A Rawlsian/Behavioral Economics Approach to Class Action Settlements, 55 EMORY L.J. 279, 280-83 (2006). 
that call into question the fairness of a settlement, and the absence of any formally-recognized opportunity to be heard, put claimants in MDL cases in even worse position than their class action counterparts.

For these reasons, the question to be asked when an MDL claimant challenges the adequacy of settlement is whether it would be a fair settlement if that claimant had been allowed to pursue her claim in the forum of original filing. That is not to say that factors affecting fairness in class suits are irrelevant in appraising MDL settlements. Of course the factors noted in Amchem and Ortiz count in MDL cases too. Both those decisions stress "structural" problems, which are certainly relevant in MDL cases too. In Amchem, structural problems included using one class to embrace persons suffering "a range of complaints" and in particular the use of one class that included "currently injured and exposure-only" people. ${ }^{193}$ In Ortiz, the Court said that when such differences appear, there should be subclasses involving representation by different lawyers, and in MDL cases a similar conclusion would require courts, at the very least, to insure membership on the PMC of lawyers representing such different interests. ${ }^{194}$ Both Amchem and Ortiz exemplify another kind of structural conflict, which came from linking class settlements with settlements of "inventory" claims, meaning that lawyers took advantage of some of leverage gained from filing class claims to gain better treatment for inventory claimants. ${ }^{195}$ Similarly in the setting of a challenge to an MDL settlement, the court should take up the question whether the MDL settlement included side deals between MDL lawyers and lawyers for the defense.

Commentators on collateral challenge to class settlements sometimes treat the matter as though it involves a kind of judicial review of the original proceedings, in which deference is due to the findings of the original judge. This view is at least defensible where judges must apply the requirements of Rule 23, and where the final settlement entails notice and a formal mechanism for objections. ${ }^{196}$ This view makes less sense

193. Amchem Prods., Inc. v. Windsor, 521 U.S. 591, 595, 626-27 (1997) (concluding settlement lacked "structural assurance of fair and adequate representation").

194. Ortiz v. Fibreboard Corp., 527 U.S. 815, 856-59 (1999).

195. Samuel Issacharoff \& Richard A. Nagareda, Class Settlements Under Attack, 156 U. PA. L. REV. 1649, 1696 (2008) [hereinafter Issacharoff \& Nagareda, Settlements Under Attack]. The inventory and class settlements are classic examples of "interdependent" settlements. See Principles of THE LAW OF AgGregate Litig. § 3.16 (AM. LAW. InSt. 2010) (interdependent settlements).

196. See, e.g., William B. Rubenstein, Finality in Class Action Litigation: Lessons from Habeas, 82 N.Y.U. L. REV. 790, 865-66 (2007) (favoring "presumption" that non-objecting class member was adequately represented; the later court should consider only record before the original court and act only if original court "made a mistake," not just because later court would do things 
with collateral challenge to MDL settlements, which entail no similar requirements or proceedings. Far preferable in the MDL setting is the proposition that the new court should consider the settlement de novo, as some courts have concluded even in class action cases. ${ }^{197}$

The Principles mostly accept the descriptions of structural issues set out in Ortiz and Amchem, but leave out claimants in different disease categories, and use the term "structural" as a limit on even direct review of aggregate settlements. ${ }^{198}$ Ortiz and Amchem, however, used the term in exemplary rather than exhaustive fashion-neither decision implies that structural issues are the only ones that merit attention. Equally striking, the Principles take the position that an aggregate settlement should not be subject to question on account of differences "created by the terms of a class settlement agreement" because such differences are not structural. ${ }^{199}$ Two Reporters on the Principles (Samuel Issacharoff and the late Richard Nagareda) attack Stephenson as exemplifying improper collateral review of facts arising after settlement. (The settlement under review there made provision for service members exposed to Agent Orange who were to become symptomatic during the ten-year period following the agreement, but not for service members who became symptomatic thereafter.) The authors suggest that the settlement was like an insurance policy given to all exposed veterans, which expired after ten years, and this ten-year cutoff was reasonable, so consideration by the reviewing court of post-litigation events in assessing the settlement's adequacy of representation was "gravely mistaken." 200

differently).

197. See Garcia v. Bd. of Educ., Sch. Dist. No. 1, Denver, Colo., 573 F.2d 676, 680 (10th Cir. 1978) (in collateral challenge to class settlement, court resolves question of adequate representation "by determining whether the interests of those who would attack the judgment were vigorously pursued and protected"); Gonzales v. Cassidy, 474 F.2d 67, 74-75 (5th Cir. 1973) (both initially and on collateral challenge, court "must stringently apply the requirement of adequate representation"); Hege v. Aegon USA, LLC, 780 F. Supp. 2d 416, 426-28 (D.S.C. 2011) (citing Hosp. Mgmt. Assocs. v. Shell Oil Co., 591 S.E.2d 611, 618 (S.C. 2004)) (asking whether collateral court is "constrained to a limited review" of "adequate procedures," or may engage in "broader, merits-based due process review," and opting for the latter) (earlier class judgment not binding on plaintiff here); Fraternal Order of Police, Sheriff's Lodge No. 32 v. Brescher, 579 F. Supp. 1517 (S.D. Fla. 1984); Keene v. United States, 81 F.R.D. 653 (S.D. W. Va. 1979) (de novo review on collateral challenge). See also Patrick Woolley, The Availability of Collateral Attack for Inadequate Representation in Class Suits, 79 TEX. L. REV. 383, 436 (2000) (adequate representation is viewed de novo on collateral challenge) (citing some of these cases).

198. See Issacharoff \& Nagareda, Settlements Under Attack, supra note 195, at 1678-79, 91-98 (citing asymptomatic versus ailing persons as raising structural issues, and interdependent settlements of inventory claims).

199. See Principles of The Law Of AgGregate Litig. § $2.07 \mathrm{cmt}$. d.

200. Issacharoff \& Nagareda, Settlements Under Attack, supra note 195, at 1687-88 (difference within Agent Orange class did not exist at time of settlement, hence "could not possibly skew the 
In the Reporter's Notes, the Principles make the same point: The approach of the Second Circuit in Stephenson turned on "a distinction that did not exist at the time of class certification but, rather, was the creation of the class settlement itself." 201

It is not at all clear, however, that the Principles draw an intelligible line, or that the Agent Orange settlement is aptly likened to an insurance policy with reasonable exclusions. The service people who became ill after 1994 had been exposed to Agent Orange in Vietnam just as those who became symptomatic after settlement but prior to 1994; the judgment purported to bind them; the lawyers purported to represent their interests. ${ }^{202}$ Whether it was or was not reasonable to take the position that causation is too attenuated for those who became ill more than ten years after the settlement is one thing, but to bar inquiry into the matter in a later assessment of fairness is quite another.

\section{Perspectives And DoubTs}

Opening up MDL product liability settlements to collateral challenge, as this article suggests, may drive down the price defendants are willing to pay for peace and may even lessen the possibility of global settlements. If establishing a checking mechanism is a good idea at all, the justification must be that this price is worth paying because such settlements are deeply problematic.

It is hard to gauge this price and this benefit because we have nothing against which to compare the settlements achieved in the Vioxx and the Diet Drugs cases. The same dilemma confronted the Court in Amchem, where Justice Breyer began his dissent from the ruling that threw out the settlement by asserting that the majority underestimated "the need for settlement." ${ }^{203} \mathrm{He}$ went on to stress that thousands of asbestos claims remained pending, that transaction costs of individual litigation were eating up sixty-one cents of every dollar of recovery, and that ongoing litigation was delaying and perhaps denying recovery for

design of any settlement").

201. See Principles of the LaW of Aggregate Litig. $§ 2.07 \mathrm{cmt}$. d (adding that "Stephenson has not garnered much following in subsequent case law").

202. See Patrick Woolley, Collateral Attack and the Role of Adequate Representation in Class Suits for Money Damages, 58 U. KAN. L. REV. 917, 936 (2010) (criticizing insurance analogy; "it was clear at the time of settlement that some veterans would receive no compensation simply because they would suffer injury after 1994").

203. Amchem Prods., Inc. v. Windsor, 521 U.S. 591, 630 (1997) (Breyer, J., concurring in part and dissenting in part). 
people exposed to asbestos four decades earlier. ${ }^{204}$ Against these benefits it may seems to be a sterile and technical argument to stress procedural standards. Maybe it's time to stop catering to the "lone wolf" mentality that insists that personal injury claims should go forward on an individual basis, stop sympathizing with plaintiffs' lawyers who "bridle at having to heed the judgment of others," who just want to do things "their own way," and to adopt the apparent view of the MDL Panel that "nineteenth-century attitudes must give way to twenty-first-century litigation realities." 205

But we have no reason for confidence in the justice of those settlements either. With no checks in place, with negotiations conducted by self-interested lawyers aided by courts who signal strongly that they want the cases settled, we have good reason to doubt that we are doing justice. $^{206}$

The asbestos cases may hold an additional lesson: One of the motive forces behind the move to aggregate is the conviction that mass tort suits simply cannot be handled on an individual basis - that "twenty-firstcentury litigation realities" don't permit it. But after the failure of the Amchem settlement the MDL Panel transferred thousands of pending claims to Judge Eduardo Robreno of the Eastern District of Pennsylvania, who managed to coordinate procedures leading to trials by consent before several judges and magistrates in that district, which in turn resolved almost two hundred thousand cases, ${ }^{207}$ on principles utilizing some threshold standards to weed out weak claims but otherwise "disaggregated" cases so that "each claim against each defendant" could "stand on its own merit[s]."208 In an echo of Professor Marcus' comment, Judge Robreno said that trial judges are "by their nature and culture lone wolves who act alone in the execution of their duties," 209 and there is reason to conclude that his handling of the asbestos cases succeeded where aggregation failed.

204. Id. at 630-32 (quoting Report of THE Judicial Conference AD Hoc COMMitTeE ON AsBestos LiTigATION 13 (Mar. 1991)).

205. Marcus, Maximalist Use of MDL's Transfer Power, supra note 20, at 2268-69.

206. See Koniak, supra note 119, at 1797-99 (arguing for collateral review of class settlements of mass tort cases and defending her view that "the class action world is full of abuse" by describing the incentives and procedures leading to class settlements and suggesting that "one does not need a world-class economist to predict that those who are not at the bargaining table will get the short end of the stick").

207. See Hon. Eduardo C. Robreno, The Federal Asbestos Product Liability Multidistrict Litigation (MDL-875): Black Hole or New Paradigm?, 23 WIDENER L.J. 97, 180-85 (2013).

208. Id. at $186-88$.

209. Id. at $188-89$. 


\section{CONCLUSION}

MDL gathering in product liability cases is not going to end soon, and settlement is far and away the most likely outcome. Perhaps such settlements can be fair and adequate, and a settlement that delivers compensation and ends litigation is good at least to that extent.

Still, the conditions that produce such settlements do not inspire confidence. The transferee court that handles every such case lacks sanction or standard that is normally found in Rule or statute, and yet this court exercises considerable influence over the course of proceedings and is motivated to clear gathered cases from the docket in a single resolution. The lawyers who run the suit for the claimants are handpicked by the transferee judge and put under pressure to settle. These lawyers cannot realistically threaten trial if negotiations lead to a lowball offer, and they are motivated to settle too, if only to recoup their investment in the litigation and make a profit. The transferee court, unsure of its authority to review any proposed settlement, nevertheless reviews it while being motivated itself to approve a settlement in order to end what would otherwise be major and scattered litigation. Sidelined lawyers for many if not most of the claimants are not in good position to object or influence events, and are pushed toward going along with whatever is proposed by the lawyers who run the case with the judge's approval. And these lawyers are likely to prevail upon their clients to go along too.

What is missing and needed is a mechanism to check the fairness and adequacy of MDL product liability settlements. In the setting of class suits, there is precedent for collateral review on behalf of class members who are included in class settlements. Such review should be available for MDL product liability settlements too. A dissatisfied settling claimant should be able to bring suit and raise these questions. A second court should be able to set aside an MDL settlement if it is unfair or inadequate, when compared to the relief that such client could reasonably anticipate in a suit of her own. Only in such a setting can we have any confidence that fairness and adequacy have been adequately attended to. 